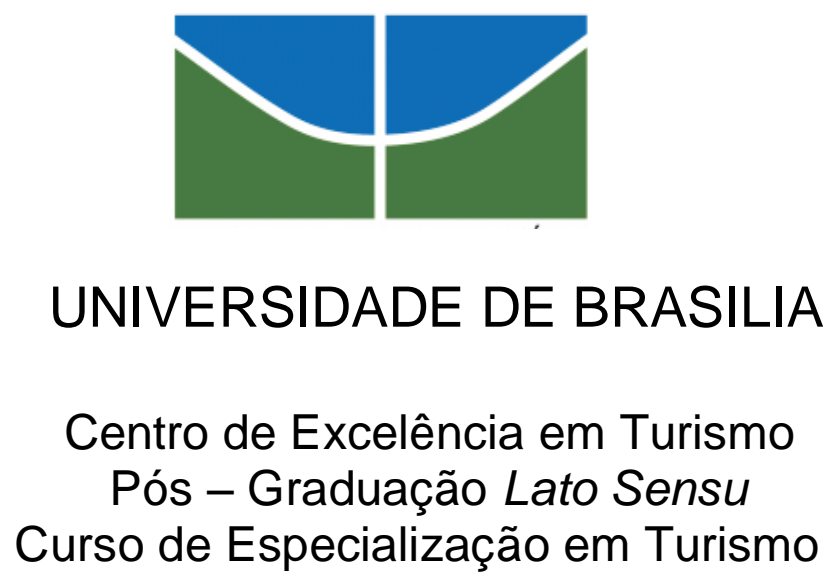

CALDAS NOVAS - PATRIMÔNIO EM RISCO

PATRICIA GUERRA PINHEIRO LEAL

Prof. ${ }^{a}$ Dr. ${ }^{a}$ Raquel Naves Blumenschein

Brasília - 2009 


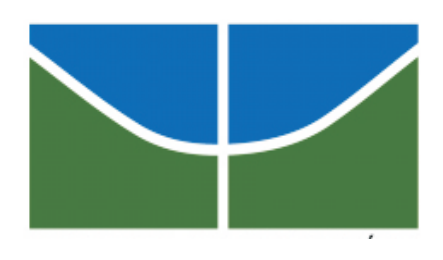

\author{
UNIVERSIDADE DE BRASÍLIA \\ Centro de Excelência em Turismo \\ Pós - Graduação Lato Sensu \\ Curso de Especialização em Turismo
}

\title{
CALDAS NOVAS - PATRIMÔNIO EM RISCO
}

\section{PATRICIA GUERRA PINHEIRO LEAL}

Monografia apresentada ao Curso de Especialização em Formação de Professores na área de turismo da Universidade de Brasília-UnB como requisito parcial para obtenção do título de especialista em Turismo.

Orientador (a): Prof.. Dr. ${ }^{-}$Raquel Naves Blumenschein. 
PINHEIRO LEAL, Patrícia Guerra.

Caldas Novas - Patrimônio em Risco/ Patrícia Guerra Pinheiro Leal Brasília, 2009.

iv, $66 \mathrm{f}$. il.

Monografia (formação de professores) - Universidade de Brasília, Centro de Excelência em Turismo, 2009.

Orientador: Raquel Naves Blumenschein.

Turismo. 2. Patrimônio. 3. Brasil. I. Turismo. Caldas Novas - Patrimônio em Risco. 


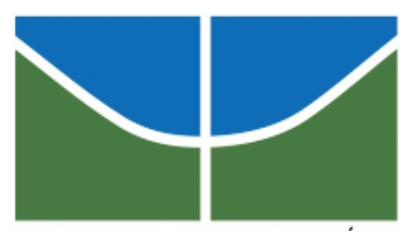

UNIVERSIDADE DE BRASÍLIA

Centro de Excelência em Turismo

Pós - Graduação Lato Sensu

Curso de Especialização em Turismo

\section{PATRICIA GUERRA PINHEIRO LEAL}

Monografia aprovada em de de 2009.

Banca examinadora:

Orientador

Prof.a Dr.a Raquel Naves Blumenschein.

$1^{\circ}$ membro:

Prof. ${ }^{\mathrm{a}}$ Dr. ${ }^{\mathrm{a}}$ Ellen Fensterseifer Woortmann

Brasília, 2009 


\section{AGRADECIMENTOS}

Ao Secretário de Obras da cidade de Caldas Novas, Sr. Ciro Tomé Pereira; Ao Secretário de Turismo da Cidade de Caldas Novas, Sr. Ari Schnitz;

Ao Delegado Dr. Lanivaldo José Mendes, responsável pelo Policia Civil da cidade de Caldas Novas;

Ao Sr. José Martini, dono da loja Serra Verde de Caldas Novas;

Aos funcionários da Secretaria de Comunicações da cidade de Caldas Novas;

Aos funcionários do Hotel Di Roma Fiori de Caldas Novas;

Aos Comerciantes da cidade de Caldas Novas, pelo apoio recebido durante minha pesquisa.

A minha orientadora, Prof. ${ }^{\mathrm{a}}$ Dr. ${ }^{\stackrel{a}{ }}$ Rachel Naves Blumenschein.

A coordenadora do curso Prof. $\stackrel{\text { a }}{\text { Dr}} \stackrel{\text { a }}{\text {. Sandra Lestinge. }}$

Ao CET, em especial, Prof. ${ }^{\text {a }}$ Dr. ${ }^{a}$ Maria de Fátima Guerra de Sousa, Thiago Ritter e Gleison Carvalho. 
A memória na qual cresce a História que por sua vez a alimenta, procura salvar o passado para servir ao presente e ao futuro. Devemos trabalhar de forma que a memória coletiva sirva para a libertação e não para a servidão dos homens.

Jacques Le Goff 


\section{LISTA DE ILUSTRAÇÕES}

Ilustração 1 - Vista da Serra de Caldas........................................................23

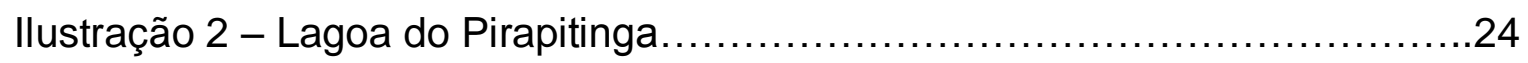

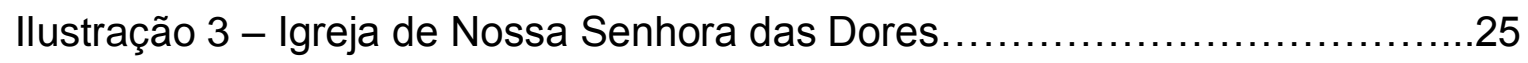

Ilustração 4 - Hotel abandonado na entrada da cidade.....................................28

Ilustração 5 - Esqueleto abandonado na entrada da cidade..............................28

Ilustração 6 - Edificações erguidas no centro de Caldas Novas...........................29

Ilustração 7 - Chalés recém construídos perto do Aeroporto...............................29

Ilustração 8 - Praça da Matriz de Caldas Novas...................................................

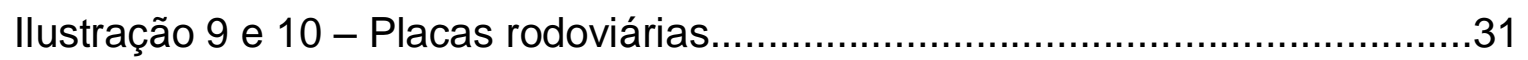

Ilustração 11 - Posto da Polícia Militar Rodoviária............................................32

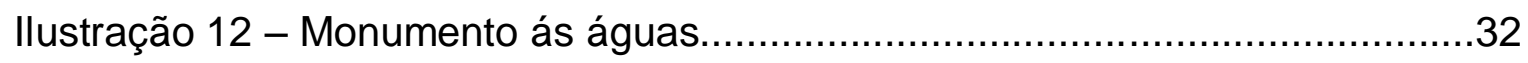

Ilustração 13 - Rodoviária Henrique Santillo...................................................33

Ilustração 14 - Praça Rosemira Jacinta Lima....................................................34

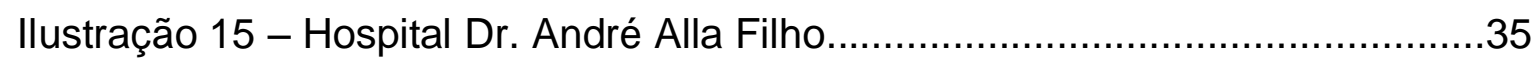

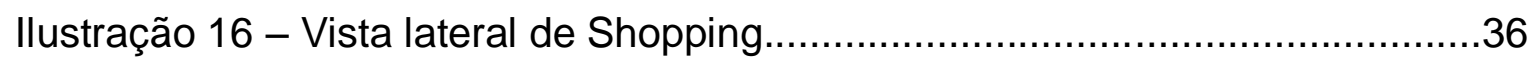

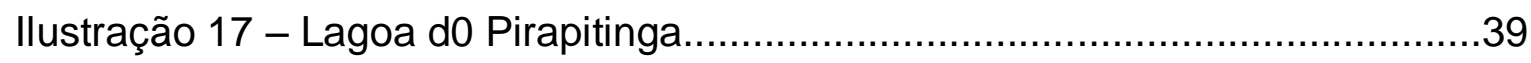

Ilustração 18 - Entrada do clube Lagoa Termas Parque.....................................39

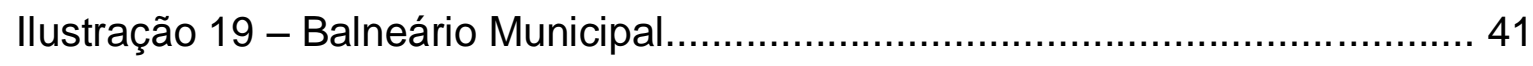

Ilustração 20 - Prédios residenciais e hotéis.................................................. 43

Ilustração 21 - Centro da cidade de Caldas Novas........................................ 44

Ilustração 22 - Ribeirão Pirapitinga............................................................... 45

Ilustração 23 e 24 - Aeroporto de Caldas Novas..............................................

Ilustração 25, 26 e 27 - Entrada da Cidade de Caldas Novas............................. 60 


\section{Lista de Siglas}

PDCN Plano Diretor de Caldas Novas.

SPHAN Serviço do Patrimônio Histórico e Artístico Nacional.

EMBRATUR Empresa Brasileira de Turismo.

SUDENE Superintendência de Desenvolvimento do Nordeste.

PCH Programa de Cidades Históricas.

BrasiliaTur Secretaria de Turismo do Distrito Federal. 


\section{Lista de Tabelas}

Tabela 1 - Gargalos do Turismo ...................................................51 


\section{SUMÁRIO}

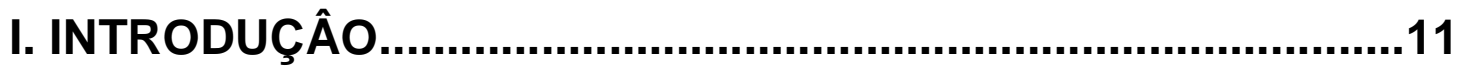

II. PRESSUPOSTOS TEÓRICOS................................................ 14

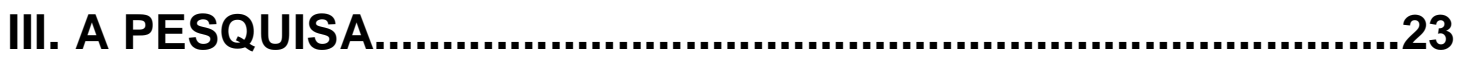

3.1 História da cidade de Caldas Novas................................. 23

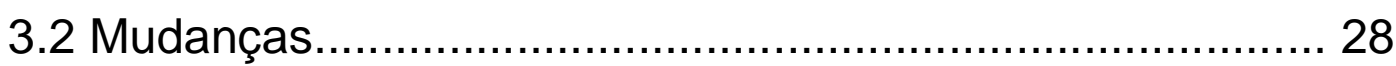

3.2.1 Alteração da Paisagem............................................ 28

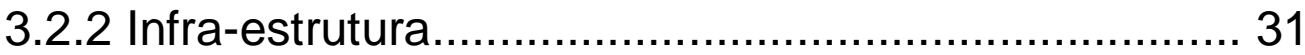

3.2.3 Gastronomia e Divulgação dos Patrimônios Históricos.............................................................. 37

3.2.4 Patrimônio Histórico - Cultural................................... 39

$3.3 \mathrm{O}$ que está sendo feito..................................................... 42

3.3.1 Gargalos do Turismo..........................................................

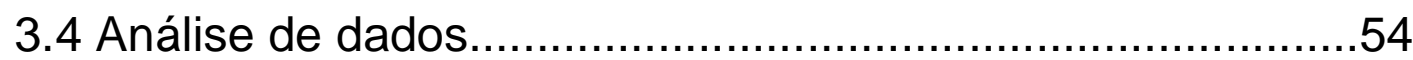

IV. CONSIDERAÇÔES FINAIS.................................................. 58

REFERÊNCIAS BIBLIOGRÁFICAS....................................... 61

ANEXO A

ANEXO B

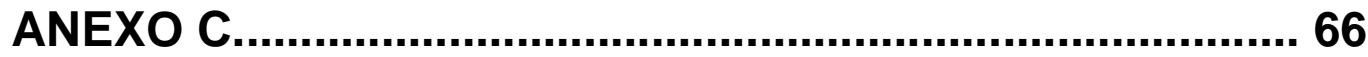




\section{RESUMO}

A cidade de Caldas Novas, localizada na Região Centro - Oeste brasileira está passando por visíveis transformações. Estas transformações envolvem o patrimônio histórico, ambiental, cultural e gastronômico da cidade. $O$ Turismo ascendente tem provocado impactos ao patrimônio histórico cultural, bem como a população local. A especulação imobiliária, a falta de planejamento e a centralização do poder nas mãos dos empresários hoteleiros também podem ser considera fatores de transformação do cenário turístico da cidade.

PALAVRAS - CHAVE: Caldas Novas. Impactos do Turismo. 


\section{ABSTRACT}

The city of Caldas Novas, which is located in the Brazilian MiddleEast region, is going through changes. These changes concern the historical and cultural patrimony, the environment as well as the city gastronomical tradition. The touristic activities, which are increasing day by day, are introducing new aspects that are modifying the historical and cultural places as well as some of its traditional aspects and are also producing effects over the local community. The real - state increasing business, the lack of planning and the hotels enterprisers overpower, can also be considered problems that are changing the city touristic scenery.

KEY - WORDS: Caldas Novas. Touristic Impacts. 


\section{INTRODUÇÃO}

A cidade de Caldas Novas está localizada a 156 km de Goiânia, capital do estado de Goiás, e a 295 km de Brasília, capital do País. Pertencente ao Bioma Cerrado e Mata Atlântica, ela representa um ponto de desenvolvimento econômico e turístico importante para a região Centro - Oeste.

Considerada a maior estância hidromineral do mundo, Caldas Novas possui atualmente 86 poços em atividade, bombeando $1.200 \mathrm{~m}^{3}$ de água quente por hora, em regime de 14 horas diárias e sua rede hoteleira oferece, aos turistas, em torno de 12 mil leitos, de acordo com informações do site CALDAS NOVAS: Brasil - O maior manancial hidrotermal do mundo.

O crescimento turístico urbano, que ocorreu a partir da década de 70 , provocou mudanças visíveis na cidade. Na pesquisa realizada por Clóvis Cruvinel sobre a especulação imobiliária em Caldas Novas - GO, ele coloca que o crescimento urbano da cidade é fruto desta especulação. Segundo Clóvis,

O desenvolvimento do turismo conferiu a cidade um modelo de urbanização muitas vezes superior ao se próprio ritmo de crescimento, onde, por exemplo, nos dias atuais, o número de leitos é maior que sua demanda.

(SILVA JUNIOR, 2007, p. 06)

Ele acrescenta ainda que:

O mais grave e maior problema da cidade é a sua desarticulação e desestrutura administrativa que vive em mãos de imobiliárias que trabalham a especulação aliadas ao poderio centralizado de empresários hoteleiros.

(SILVA JUNIOR, 2007, p.06) 
Diante disto, este trabalho tem por objetivo:

> Geral: > analisar e avaliar as principais mudanças ocorridas na cidade de Caldas Novas.

Específicos: > demonstrar o crescimento desordenado da cidade;

> apontar a aculturação gastronômica que está ocorrendo;

> apresentar os problemas causados ao patrimônio da cidade.

Os procedimentos metodológicos utilizados nesta pesquisa foram:

$>$ Estudo de caso: > visa analisar o que está ocorrendo na cidade de Caldas Novas, procurando identificar os fatores que determinam os problemas causados ao patrimônio, através de observação participante, entrevistas não diretivas, semi-estruturadas e documentos.

Recursos: > fotografia, mapa do zoneamento urbano e Plano Diretor de Caldas Novas.

Fazem parte da estrutura desta monografia, os seguintes itens:

> História da Cidade de Caldas Novas.

> Mudanças: > Alteração da Paisagem;

$>$ Infra-estrutura;

> Gastronomia e Divulgação dos Patrimônios Históricos; 


$$
\begin{aligned}
& \text { >Patrimônio Histórico - Cultural; } \\
& \text { > O que está sendo feito (análise do PCDN); } \\
& \text { > Análise de dados. }
\end{aligned}
$$

A contribuição desta pesquisa está baseada na preservação do patrimônio histórico e cultural, pois preservar o patrimônio significa manter viva a memória coletiva de um povo. De acordo com Castro Neves:

Torna-se fundamental enfatizar a importância desse patrimônio como suporte da história e da memória dos grupos sociais. Em outros termos, os bens patrimoniais são instrumentos importantes de identidade dos grupos sociais.

(CASTRO NEVES, 2003, p.53)

Por esta razão, preservar o patrimônio da cidade de Caldas Novas significa manter viva, para as gerações futuras a memória coletiva da cidade.

Para tanto, este trabalho procura demonstrar os problemas causada à memória da cidade de Caldas Novas que, atualmente, se encontra envolvida pela especulação imobiliária e pela aculturação.

Por estar de posse de patrimônios tanto naturais, como suas águas termais, e históricos como a Lagoa de Pirapitinga, passagem de bandeirantes que fazem parte da história deste país, a cidade de Caldas Novas precisa de uma maior atenção do Poder Público. Portanto, o propósito desta pesquisa encontrase no fato de demonstrar os problemas que esta cidade enfrenta, nos dias de hoje, para manter vivo seu patrimônio. Sugestões para um planejamento estratégico que leve a sustentabilidade da cidade serão analisados, assim como, a exposição de fotos referentes às transformações pelas quais a cidade vem passando. 


\section{PRESSUPOSTOS TEÓRICOS}

Este trabalho está ancorado, basicamente, em dois fundamentos: Sustentabilidade e Memória Coletiva. Isto porque, estes dois fundamentos são os alicerces para a preservação do patrimônio. Por fazer parte do fundamento Sustentabilidade, o Planejamento Sustentável também será utilizado como apoio para este trabalho.

A partir da década de 70 , a concepção de que os bens naturais não eram inesgotáveis tornou-se clara para o mundo contemporâneo. A necessidade de preservação do patrimônio histórico e cultural acontece simultaneamente. Com base na crise do petróleo e no Relatório do Clube de Roma, percebeu - se que as matérias-primas e as fontes energéticas tinham seu fim. Durante a Conferência das Nações Unidas de Desenvolvimento e Meio Ambiente, a Eco 92, realizada no Rio de Janeiro, a Agenda 21 propõe um modelo de desenvolvimento sustentável.

Segundo Buarque,

o conceito de desenvolvimento sustentável resulta do amadurecimento das consciências e do conhecimento dos problemas sociais e ambientais e das disputas diplomáticas, mas também de várias formulações acadêmicas e técnicas que surgem durante as três últimas décadas com críticas ao economicismo e defesa do respeito ao meio ambiente e as culturas. (BUARQUE, 2002, p. 58).

Buarque explica que, com o crescimento das atividades econômicas há uma degradação e conseqüente destruição do meio ambiente e dos recursos naturais que, se não controlada, provocará uma estagnação no desenvolvimento econômico, comprometendo a qualidade de vida da população. 
A necessidade de se enxergar que as fontes energéticas têm seu fim exige políticas públicas voltadas para bem-estar das gerações futuras. Buarque cita a Comissão Brundland para definir desenvolvimento sustentável: "é aquele que satisfaz às necessidades do presente, sem comprometer a capacidade das gerações futuras satisfazerem as suas próprias necessidades." (Buarque, p. 59,60).

Para Ruschmann (2008, p. 111) "a perpetuação da atratividade turística é, portanto, a base do desenvolvimento sustentável do turismo.". Deve-se, então, considerar que todo produto turístico é finito, caso não haja um planejamento sustentável que tenha a preocupação de evitar prejuízos aos meios turísticos, a aculturação da comunidade local e que, ao mesmo tempo, possa desenvolver as potencialidades locais.

Turismo e desenvolvimento sustentável estão interligados. Esta ligação se deve ao fato de que o turismo precisa utilizar o desenvolvimento sustentável para preservar patrimônios naturais e culturais.

O Turismo, infelizmente, provoca danos ao meio ambiente como poluição, influência de culturas externas à população nativa, falta de infraestrutura para comportar o fluxo turístico, dentre outros. Atualmente, o turismo de massa vem sendo apontado como "destruidor" do patrimônio natural e cultural. Isto acontece, principalmente, pelo total despreparo do turista que assume não ter nenhuma responsabilidade com relação à preservação do patrimônio por ele visitado. Acredita - se também que, por efetuar um pagamento de quantia previamente estabelecida, possui, com isto, o direito de depredar o patrimônio.

Além de se educar o turista, o preparo e conscientização da comunidade local são fatores importantes. 
Para receber bem o turista e saber que ele voltará, faz-se necessário que os receptores tenham conhecimento das exigências do turista, bem como possam the atender de maneira cortes, contudo utilizando de profissionalismo. Portanto, habilitar a mão-de-obra precisa ser uma das prioridades dos empresários responsáveis pelo atendimento direto ao turista. Conscientizar a população de que receber bem o turista, Ihe "renderá frutos" é, também, um aspecto importante, pois o Turismo nunca deixará de ser uma atividade econômica. Não basta ter uma placa de "Boas-Vindas" na entrada da cidade e outra dizendo "Volte Sempre". È necessário que todos causem boa impressão.

Uma das ações que tem forte impacto positivo na sustentabilidade da atividade turística é a gestão participativa, onde a própria comunidade toma para si, a responsabilidade de planejar e preservar seu patrimônio. Fazendo parte desta comunidade, estão os agentes formais e informais, que são os realizadores deste processo. Os primeiros são aqueles ligados ao Poder Público como a administração pública representada pelo prefeito, câmara dos vereadores, secretários, juízes, além dos representantes da igreja, professores, etc. Quanto aos agentes informais, estes são representados pelos líderes comunitários, empresários, moradores, etc.

Portanto, este é o grupo que deve compor uma assembléia aberta a discussões sobre a melhor forma de se implementar o tipo de turismo mais adequado à comunidade. Somente quando se busca um modelo de sustentabilidade turística através da união entre o Poder Público e a comunidade é que problemas serão solucionados de forma a atender tanto ao turista como a população local.

Assim como a Gestão Participativa, a educação para o turismo necessita ser amplamente utilizada. 
Há a necessidade de se preparar o turista, tornando-o um hóspede que respeita as diferenças relativas à população hospedeira, preserva os patrimônios, bem como, o meio ambiente.

Ferreira coloca como sugestão, por exemplo, respeitar a capacidade local para receber o turista, aplicando planos e políticas públicas para este controle. Integrar a comunidade local na participação da atividade turística, preparando-a tecnicamente e planejar, para que as atividades turísticas não sobreponham às atividades e tradições já existentes na comunidade também fazem parte de suas sugestões. (FERREIRA, p. $6-7$ ).

Em outras palavras, o que Ferreira chama atenção é para a necessidade de um planejamento turístico sustentável. Para que este planejamento aconteça, necessita-se que o Estado elabore objetivos que se iniciam pela infra-estrutura básica que dará suporte tanto ao turista quanto a população local. Além destes, deve haver uma preocupação com a preservação do patrimônio ambiental, assim como, com a regulamentação para que serviços e equipamentos funcionem adequadamente para o atendimento das necessidades do turista.

Planejamentos bem estruturados solucionam, com mais eficácia problemas e na maioria das vezes, até os evitam. Por esta razão, durante a formulação de um planejamento, o profissionalismo é de extrema importância para que seja evitado um desenvolvimento inadequado, que no passado era provocado pelo amadorismo.

Outro ponto a ser considerado em um planejamento de sucesso é a abrangência, ou seja, não se deve considerar apenas uma localidade ou um recurso. Faz-se necessário observar as peculiaridades culturais e econômicas da região. 
Um planejamento turístico realizado a longo prazo possui maior chance de êxito, pois o tempo de sua realização é estimado em mais de vinte anos. Por conceber a idéia de um produto turístico de maior duração, este planejamento não deve ter objetivos radicais, e sim adequar às potencialidades locais aos novos produtos resultantes do original.

Em um planejamento a médio prazo, o objetivo é colocar em prática as diretrizes propostas no planejamento a longo prazo. No período de cinco anos, espera-se que as ações relacionadas aos serviços e equipamentos designados ao atendimento das necessidades e interesses da demanda turística sejam implantadas.

A preparação dos núcleos receptores, através do treinamento de recursos humanos, visando o funcionamento adequado de equipamentos e serviços são pontos que fazem parte do planejamento a curto prazo, que possui duração média de um ano.

Enquanto que os planejamentos de médio e longo prazo são implementados pelo Poder Público, por serem de alto custo, o planejamento a curto prazo é, normalmente, implantado por empreses privadas e prefeitura.

Sobre planejamento turístico, Ruschmann firma que:

Ele tem por objetivo o desenvolvimento coerente dos elementos físicos, econômicos, sociais, culturais, técnicos e ambientais, para satisfação de turistas e empresários, e deve, necessariamente, estar inserido em uma política global, empreendida pelo governo.

(RUSCHMANN, 2008, p. 100)

Para funcionar de maneira integrada, o planejamento turístico precisa 
da articulação de municípios para que ações sejam compartilhadas, além do apoio financeiro e técnico do Poder Público, o qual está vinculado o produto turístico.

Além deste apoio, é importante que, por ser o turismo uma atividade interdisciplinar, a base técnica seja composta por elementos de várias áreas. Esta integração entre Poder Público e base técnica multidisciplinar, propiciará um encaminhamento correto de ações cuminando em uma implantação adequada do plano em questão.

Patrimônio é tudo aquilo que nos é deixado como herança. Ele carrega consigo a identidade da comunidade a qual pertence. $\mathrm{O}$ produto cultural desta comunidade é demonstrado através de suas tradições, obras e costumes. Portanto, se unirmos Patrimônio e Cultura, teremos a história, memória e valores de um povo. Na Conferência Mundial sobre as Políticas Culturais no México, em 1982, a Unesco define Patrimônio Cultural como "as obras de seus artistas, arquitetos, músicos, escritores e sábios, assim como as criações anônimas, surgidas da alma popular, e o conjunto de valores que dão sentido à vida." (CASTRO NEVES, p. 51).

Portanto, a memória coletiva torna-se parte de um todo chamado Patrimônio Cultural, servindo como suporte para manutenção das identidades dos grupos sociais. É também necessário que a sociedade, como um todo, preserve sua memória de forma democrática para que este patrimônio sirva as gerações futuras.

Preservar não significa congelar no tempo, mas sim conservar para as gerações futuras. O turismo, por ser uma atividade cultural, através de um planejamento estratégico, tem condições de auxiliar as comunidades a revelar seus valores. 
A respeito das formas de utilização do Turismo pela comunidade local, Castro Neves coloca que:

Conhecer lugares, assistir a apresentação de manifestações artísticas, degustar pratos típicos peculiares de cada região, compartilhar com os nativos experiência de uma feira local, é conhecer elementos que dizem respeito a pessoas e suas sensibilidades, suas normas e valores, suas emoções.

(CASTRO NEVES, 2003, p.59)

Ao final da década de 60 e início de 70 , um "ar" de modernidade pairou sobre o país, conseqüência do impulso dado ao processo de industrialização. As cidades tombadas tiveram sua paisagem modificada, deixando inquietos gestores do SPHAN. Os critérios, antes utilizados, eram agora ignorados.

O redimensionamento dos terrenos, provocado pela especulação monetária sobre a terra, diminui suas proporções eliminando os terrenos com área verde e quintais e substituindo-os por lotes aquadradados.

Ao final da década de 60, o Poder Público se interessa em discutir a questão dos núcleos urbanos tombados e inicia este trabalho pelas cidades históricas do nordeste brasileiro. A comissão interministerial contou com a presença de órgãos como o PHAN, a Embratur, a Sudene e o $\mathrm{PCH}$, Programa de Cidades Históricas. Até o final da década de 70 , este grupo teve atuação independente, quando em 1980 houve a criação da Fundação Pró - Memória a qual foi anexada o Programa $\mathrm{PCH}$.

A Fundação Pró - Memória tem como ideal, agilizar a máquina publica, assim como, remediar a carência financeira, tornando-se uma nova perspectiva para a preservação do patrimônio nacional. 
As idéias, antes colocadas pelos modernistas, especialmente por Mário de Andrade, agora são retomadas por esta Fundação. Porém, com a reforma administrativa feita pelo Governo, do então Presidente da República Senhor Fernando Collor de Mello, extingue - se este órgão e suas atribuições passam a serem realizadas pela administração direta.

Com o advento da nova Constituição Brasileira, promulgada em 1988, ocorreram modificações referentes ao conceito de patrimônio. A substituição da terminologia de patrimônio histórico e artístico para patrimônio cultural foi uma delas. Um outro ponto foi a determinação de considerar Patrimônio Cultural Brasileiro, as formas de expressão, as criações cientificas, bem como as manifestações artísticas - culturais e os núcleos urbanos e os sítios de valor histórico.

Em 2000, um decreto presidencial indica ações de referência para o registro do patrimônio imaterial.

Portanto, tornam-se patrimônios imateriais os saberes, nas formas de conhecimento, as celebrações, com seus rituais e festas e as formas de expressão demonstradas através das manifestações musicais, plásticas, teatrais e lúdicas.

Os museus e arquivos também têm recebido alguma atenção dos governos. A melhoria de sua aparência física, tornando estes espaços mais interessantes e a renovação de seus acervos, tem contribuído para a dissociação da idéia de que museu "é lugar de coisa velha".

Quando relacionamos turismo e patrimônio cultural, é necessário considerar os impactos que o turismo provoca ao demonstrar a identidade cultura e que, ao mesmo tempo, tem a obrigação de preservar a cidadania da população 
local. O turista, nada mais faz do que, realizar por um curto período de tempo, ações que para a comunidade local são corriqueiras. $O$ turismo pode trazer progresso a uma determinada região, mas pode também contribuir para a descaracterização e aculturação da comunidade local, como está acontecendo à cidade de Caldas Novas.

Por não existir um "livro de regras" as quais se deve seguir, é importante que planejamentos sustentáveis sejam realizados para que a memória e o patrimônio cultural sejam preservados, assim como, os direitos da comunidade local sejam garantidos. 


\section{A PESQUISA}

\subsection{História da cidade de Caldas Novas}

De acordo com o site CALDAS NOVAS: Brasil - o maior manancial hidrotermal do mundo, durante o período de colonização do Brasil, a região em que está localizada a cidade de Caldas Novas pertencia à capitania de São Paulo.

Em 1722, o bandeirante Bartolomeu Bueno da Silva Filho, herdeiro de Anhanguera chega à região a procura de ouro. Contudo, sua comitiva se depara com um ribeirão de águas cristalinas e quentes localizadas ao pé de uma serra, conhecida hoje, como Serra de Caldas. Impressionado com o fenômeno, segue o curso do riacho onde encontra vestígios do ouro procurado e mais outras fontes termais. A região ganha então o nome de Caldas Velhas e por um curto período de tempo, atrai visitantes, principalmente, vindo das Minas Gerais e de São Paulo em busca de curas atribuídas às águas termais.

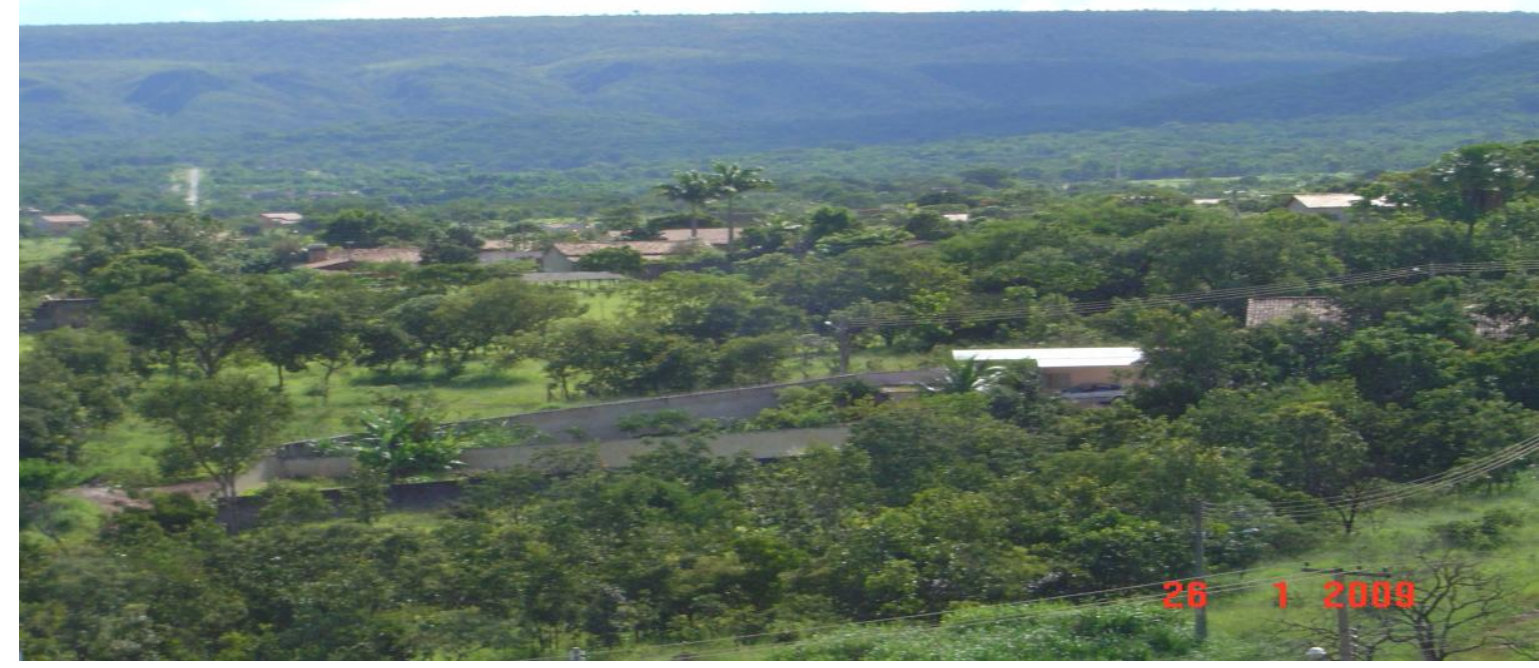

Ilustração 1. Vista da Serra de Caldas.

Foto: Patrícia Leal, janeiro 2009. 
Conforme o site CITY BRAZIL - Goiás - Caldas Novas - História da cidade, em 1770, Martim Coelho de Siqueira, toma conhecimento do ouro encontrado nas encostas da Serra das Águas Santas de Santa Cruz, denominação dada à época as Serras de Caldas. Por esta razão em 1775, mudase para Goiás e fixa residência na cidade de Santa Luzia, hoje Luziânia. Dois anos mais tarde, em 1777, acompanhado de parentes, escravos e agregados, transfere-se para a Serra de Santa Cruz e lá descobre uma lagoa com água em altíssima temperatura. Além da lagoa, Martim descobre fontes que passam a ser chamadas de Caldas de Pirapitinga e outras às margens do Córrego de Lavras.

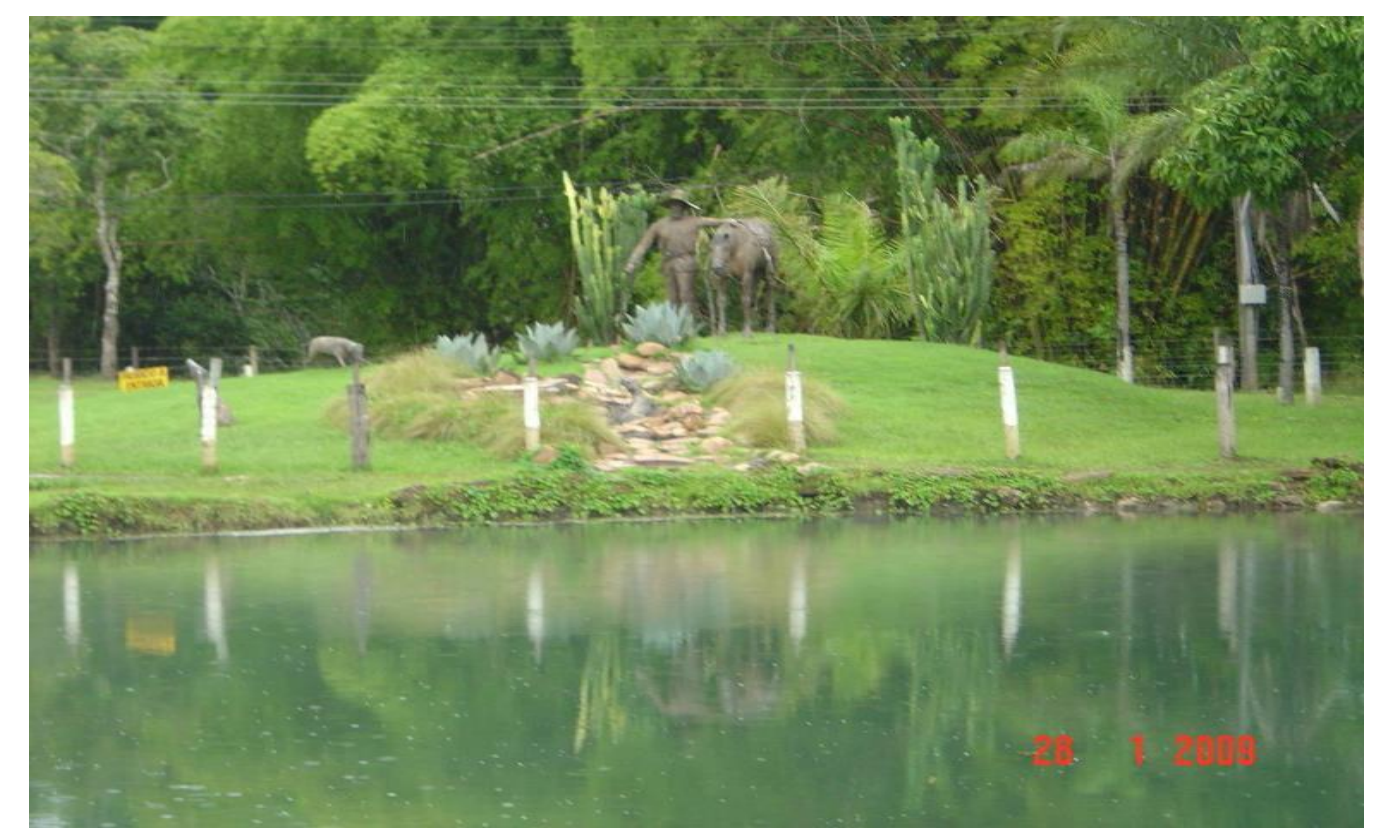

Ilustração 2. Lagoa do Pirapitinga.

Foto: Patrícia Leal, janeiro 2009.

Ao final do ano de 1788, Martim recebe do governo uma sesmaria de três léguas de terra (gleba de terra com cerca de $40 \mathrm{~km}^{2}$ ou 04 mil hectares) a qual batiza de Fazenda de Caldas. Muda também o nome do povoado que com a extração do ouro começa a se formar, de Caldas Velhas para Caldas Novas de Santa Cruz. 
No ano de 1851, Caldas Novas é elevada a categoria de distrito de Santa Cruz de Goiás. Um ano antes, em 1850, é construída uma das primeiras edificações da cidade: a igreja de Nossa Senhora do Desterro, que em 1888 teve seu nome modificado para Nossa Senhora das Dores de Caldas Novas por abrigar uma imagem da Santa. Em 1870, acontece a edificação da primeira escola.

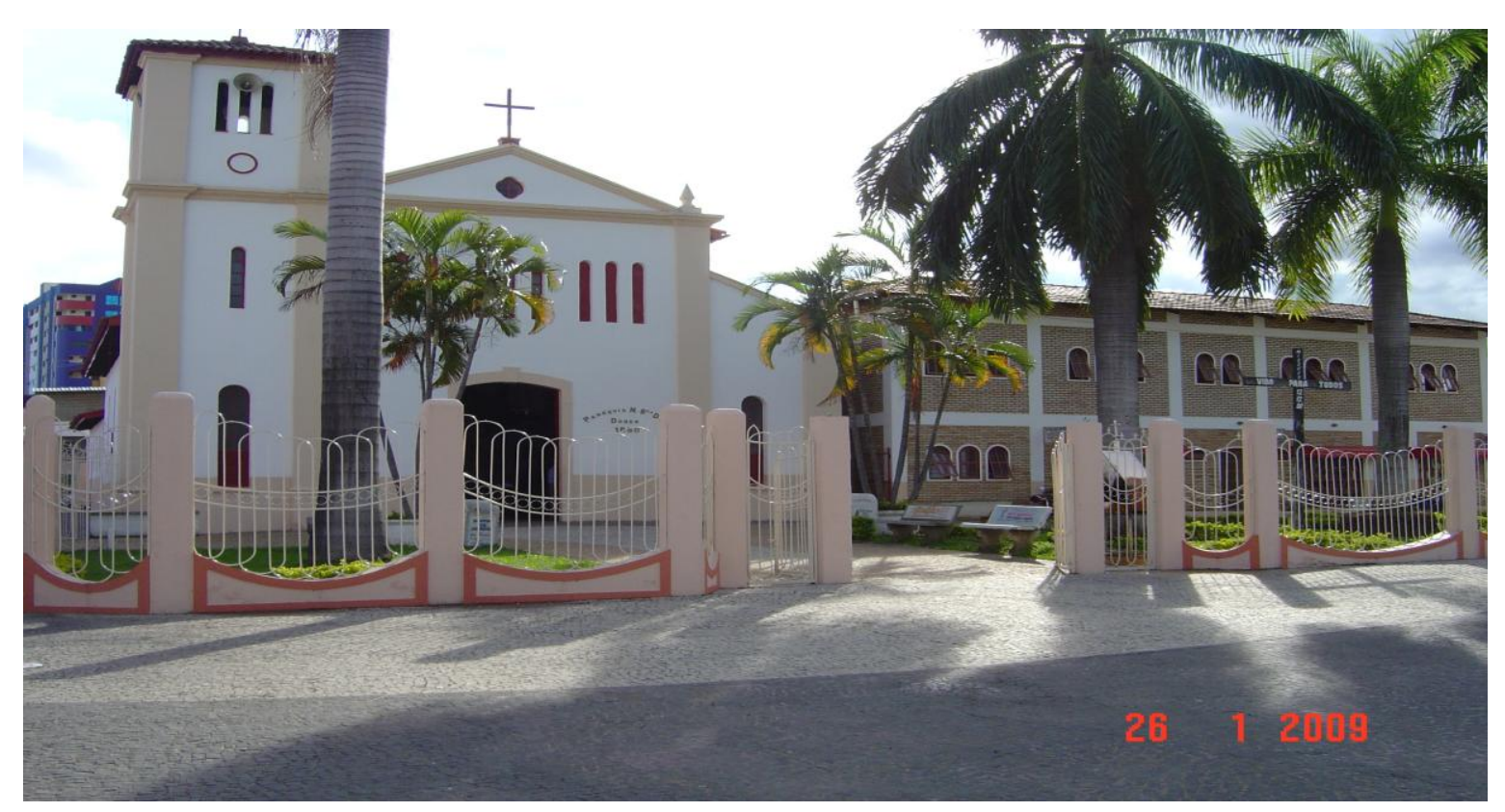

Ilustração 3. Igreja de Nossa Senhora das Dores.

Foto: Patrícia Leal, janeiro 2009.

Entre 1880 e 1893, a cidade fica sob jurisdição da Comarca de Vila Bela de Morrinhos. Pela Lei ㄲo. 393 de 05 de julho de 1911, Caldas Novas desmembra - se da Comarca de Morrinhos e passa a ter status de município sendo seu primeiro governante, o Coronel Bento de Godoy. A instalação do município se dá no dia 21 de outubro do mesmo ano, e a partir desta data, o dia 21 de outubro tornou - se a data de aniversário da cidade. 
Segundo o site CALDAS NOVAS - Go / Informações, a primeira tentativa de romper com o isolamento em que se encontrava a cidade de Caldas Novas foi a construção da Ponte São Bento sobre o Rio Corumbá. A inauguração se deu no dia 31 de janeiro de 1920, pelo então governador Coronel Bento de Godoy. A importância desta ponte está no fato de ligar Ipameri a Caldas Novas, sendo que a primeira era, na época, a última estação da estrada de ferro que ligava a região ao Centro-Sul do país. Anos depois, o engenheiro José Teófilo de Godoy constrói a estrada de rodagem até Ipameri, cidade localizada a 50 quilômetros de Caldas Novas.

Elevada a condição de cidade em 21 de junho de 1923, possui três distritos até 1943, quando passa a ser constituído de apenas dois. A partir de 1960, o município passa a ser distrito sede, assim permanecendo até os dias de hoje.

No site CITY BRASIL - Goiás - Caldas Novas - História da cidade, em 1988 os habitantes do povoado das Águas Quentes, onde está instalado, desde 1964, o resort Pousada do Rio Quente, juntamente com os dos povoados de Esplanada e Esperança, realizaram um plebiscito para que houvesse 0 desmembramento destes três municípios do município de Caldas Novas. Portanto, desde 1989, o antigo povoado das Águas Quentes tornou-se Cidade do Rio Quente e distrito sede do município que, comporta ainda os povoados de Esplanada e Esperança.

Nas últimas eleições, realizadas em 17 de fevereiro de 2008, o Senhor Ney Viturino tornou - se Prefeito do município.

Atualmente a cidade de Caldas Novas possui uma população entorno de 65.000 habitantes, em uma área de cerca $1.600 \mathrm{~km}^{2}$, segundo dados do IBGE. Seu clima é classificado como tropical quente e úmido, com chuvas nos primeiros meses do ano e temperatura anual de $24^{\circ} \mathrm{C}$. 
$\mathrm{O}$ acesso à cidade é feito por via aérea e rodoviária. As rodovias utilizadas são a BR-153, GO-213, GO-139 e GO-217. Os municípios goianos que fazem limite com a cidade são Morrinhos, Manzagão, Piracanjuba, Corumbaíba, Rio Quente, Ipameri, Santa Cruz e Pires do Rio.

Além de seu produto turístico principal que são as águas termais, cuja temperatura pode alcançar $45^{\circ} \mathrm{C}$, a maior estância hidromineral do planeta possui atrativos turísticos como: o Balneário Municipal, o Lago Represa do Corumbá, o Parque Estadual da Serra de Caldas, a Lagoa Feia ou de Pirapitinga, o Jardim Japonês, a Igreja de Nossa Senhora das Dores, a Casa de Martim Coelho conhecida como Fazenda de Caldas, o Casarão, a Feira do Luar dentre outros. 


\subsection{Mudanças}

\subsubsection{Alteração na Paisagem}

Nos últimos 20 anos a cidade de Caldas Novas vem passando por mudanças que estão provocando alterações em sua paisagem. $\mathrm{Na}$ entrada da cidade, há condomínios com chalés que estão construídos ou em construção. Todavia, existem também aqueles que foram totalmente abandonados, com o mato alto e famílias residindo em seus terrenos, como mostram as ilustrações 4 e 5.

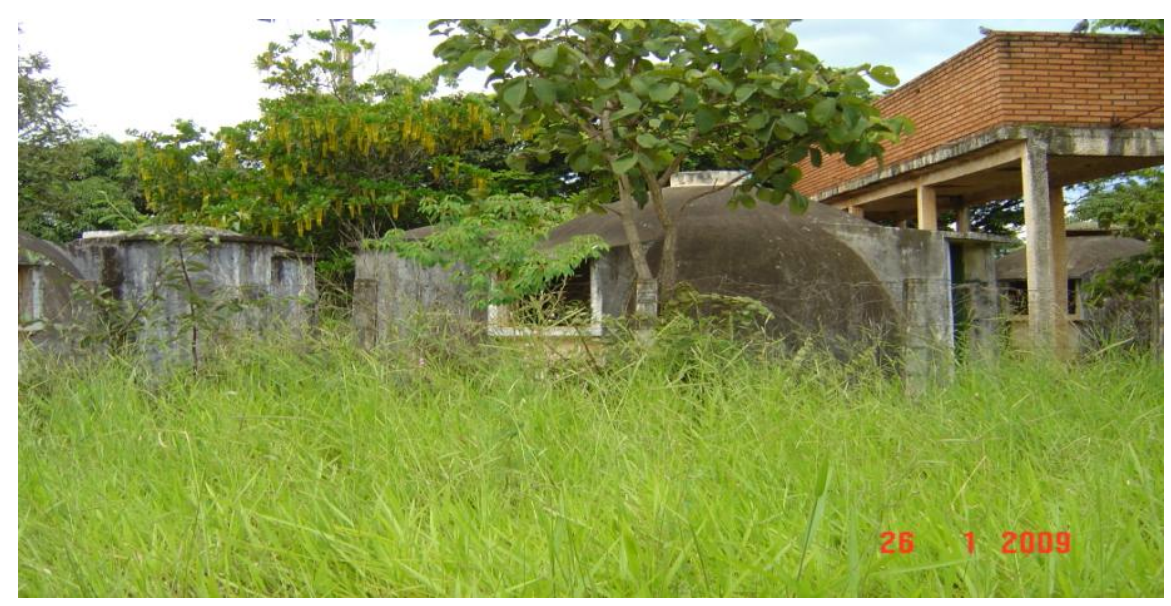

Ilustração 4. Hotel abandonado na entrada da cidade.

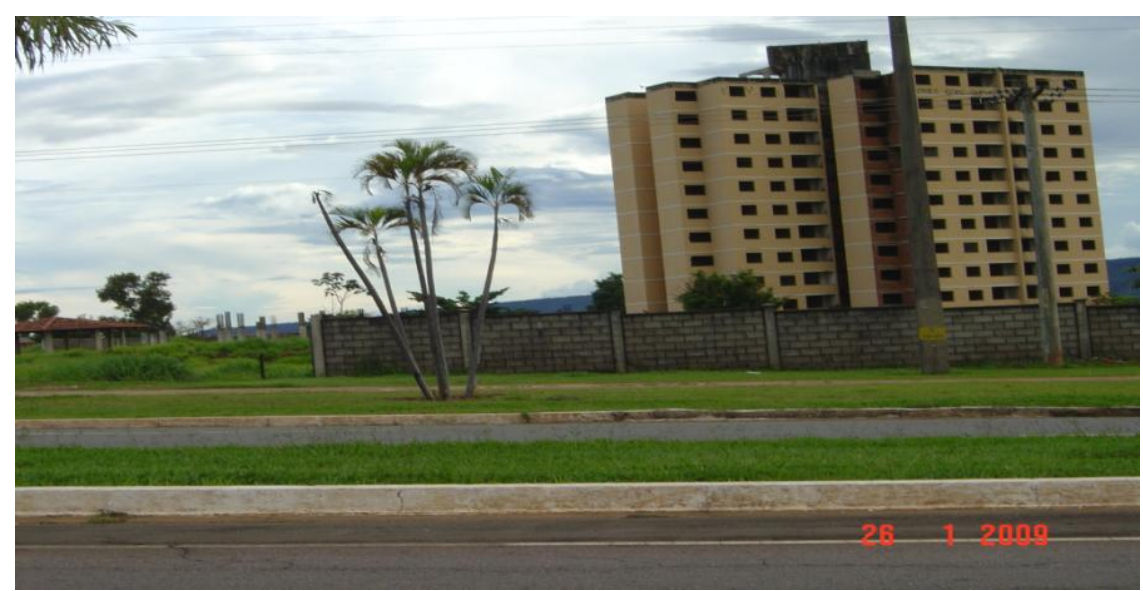

Ilustração 5: Esqueleto abandonado na entrada da cidade.

Fotos: Patrícia Leal, janeiro de 2009. 
O crescimento imobiliário é outro fator que está descaracterizando a paisagem da cidade.

A construção de altos prédios em lugar das antigas casas está deixando a região central da cidade com ares de cidade grande. Com isso, a comunidade local está sendo empurrada para a periferia, fenômeno hoje, bastante corrente nas cidades com atrativos turísticos.

Além de prédios residenciais, o crescimento imobiliário desordenado envolve a construção de hotéis e chalés por toda a cidade.

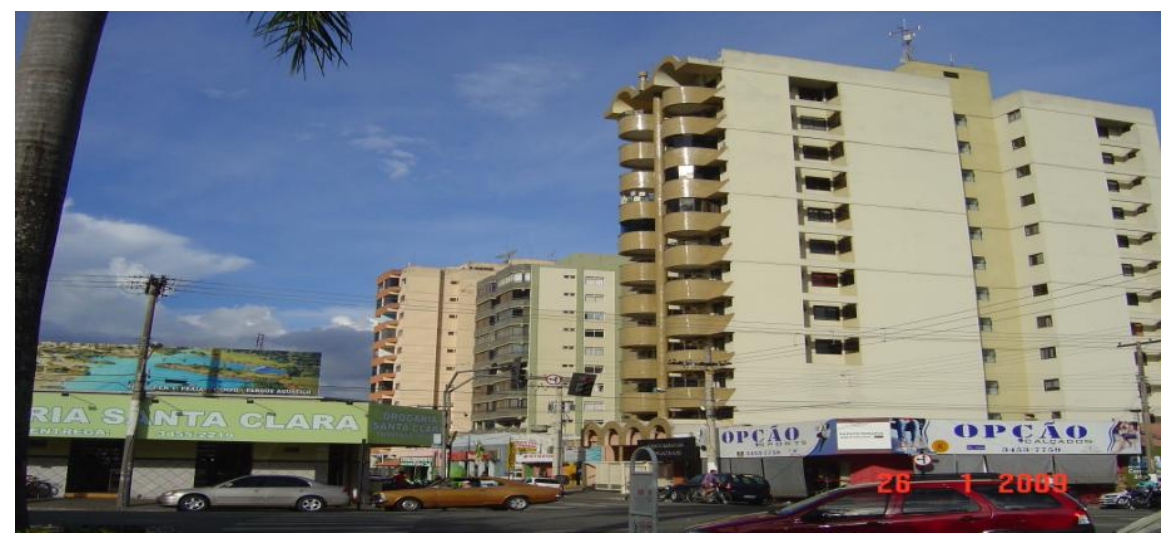

Ilustração 6. Edificações erguidas no centro da cidade.

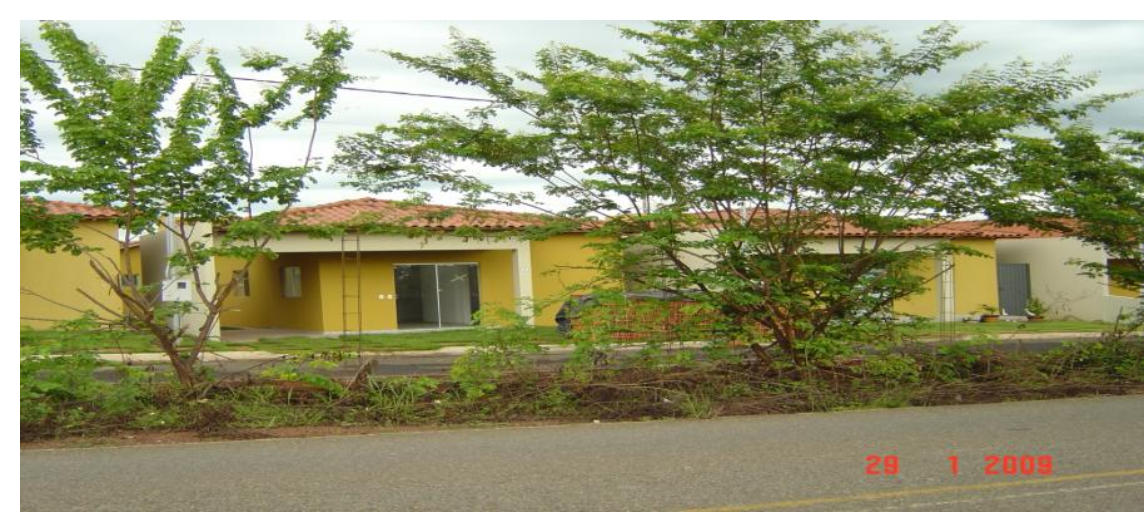

Ilustração 7. Chalés recém construídos perto do aeroporto.

Fotos: Patrícia Leal, janeiro 2009. 
Um atrativo turístico, que caracterizava a cidade de Caldas Novas, a Praça da Matriz de Nossa Senhora das Dores foi reformada. Das muitas árvores frondosas que lá havia, poucas restaram, e o coreto, antiga sede da Secretaria de Turismo e Espaço Cultural para exposições artísticas, desapareceu. Em seu lugar, existe hoje, um espaço com calçamento de pedras e palmeiras, árvores bem diferentes das vistas na região.

A Praça continua sendo um centro de encontro tanto para turistas, quanto para a população local. Porém, os bares que estão lá situados, são mais característicos de cidades como São Paulo e Brasília, com música ao vivo e pratos bem diferentes dos típicos da região.

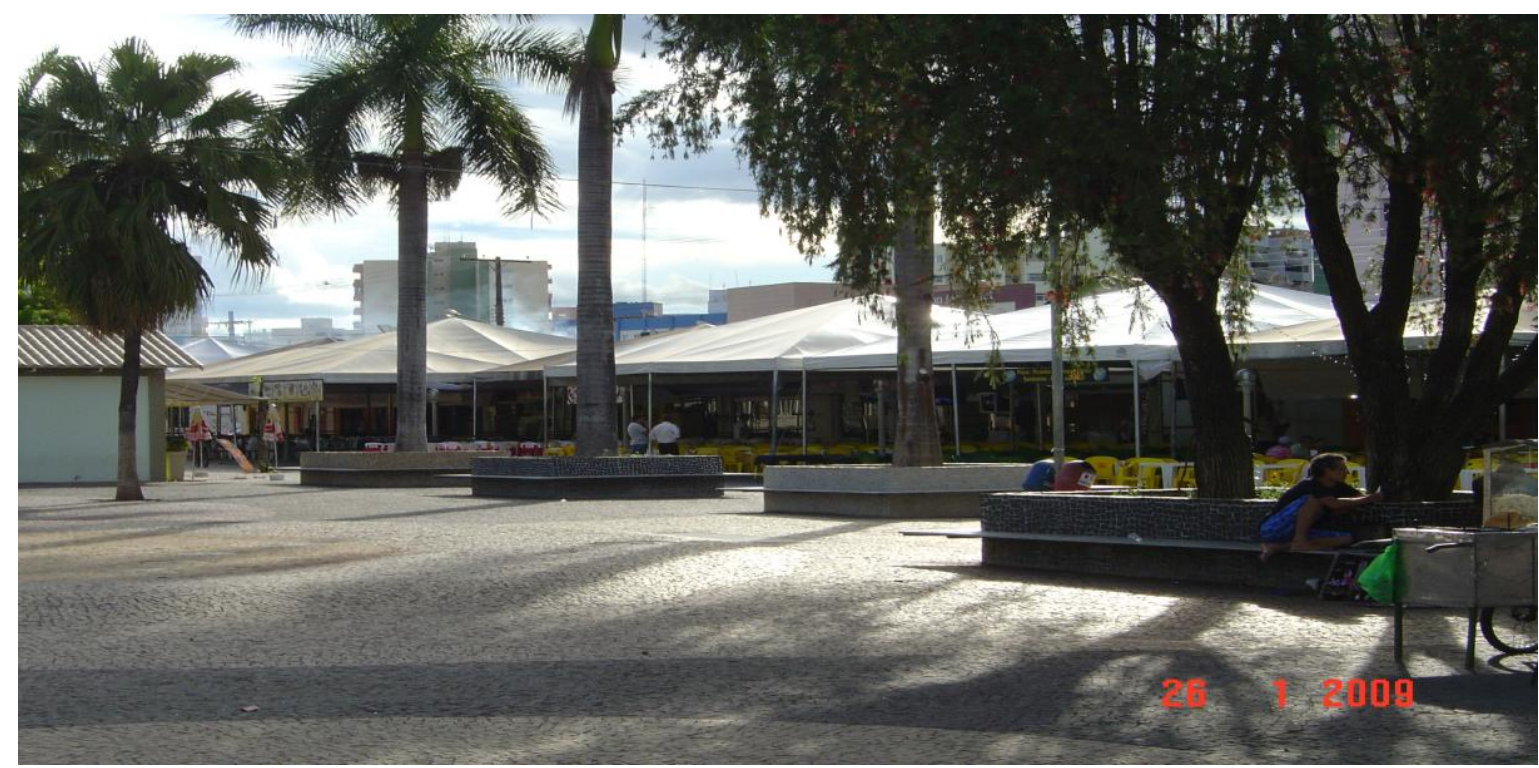

Ilustração 8. Praça da Matriz de Caldas Novas.

Foto: Patrícia Leal, janeiro 2009. 


\subsubsection{Infra - estrutura}

Na entrada da cidade de Petrópolis, no estado do Rio de Janeiro, existe um bonito portal que indica, ao turista, a importância do local a ser visitado, pois nele está escrito: Petrópolis - Cidade Imperial. Já no sul do Brasil, mais precisamente na famosa cidade de Gramado, no Rio grande do Sul, o turista visualiza um belíssimo portal, que faz lembrar castelos Europeus.

Em Caldas Novas, porém, não há nada que demonstre ao turista, em sua chegada, o fato desta cidade ser a maior estância hidrotermal do planeta, a não ser por singelas placas rodoviárias com letras coloridas, ou outra, mais simples ainda.
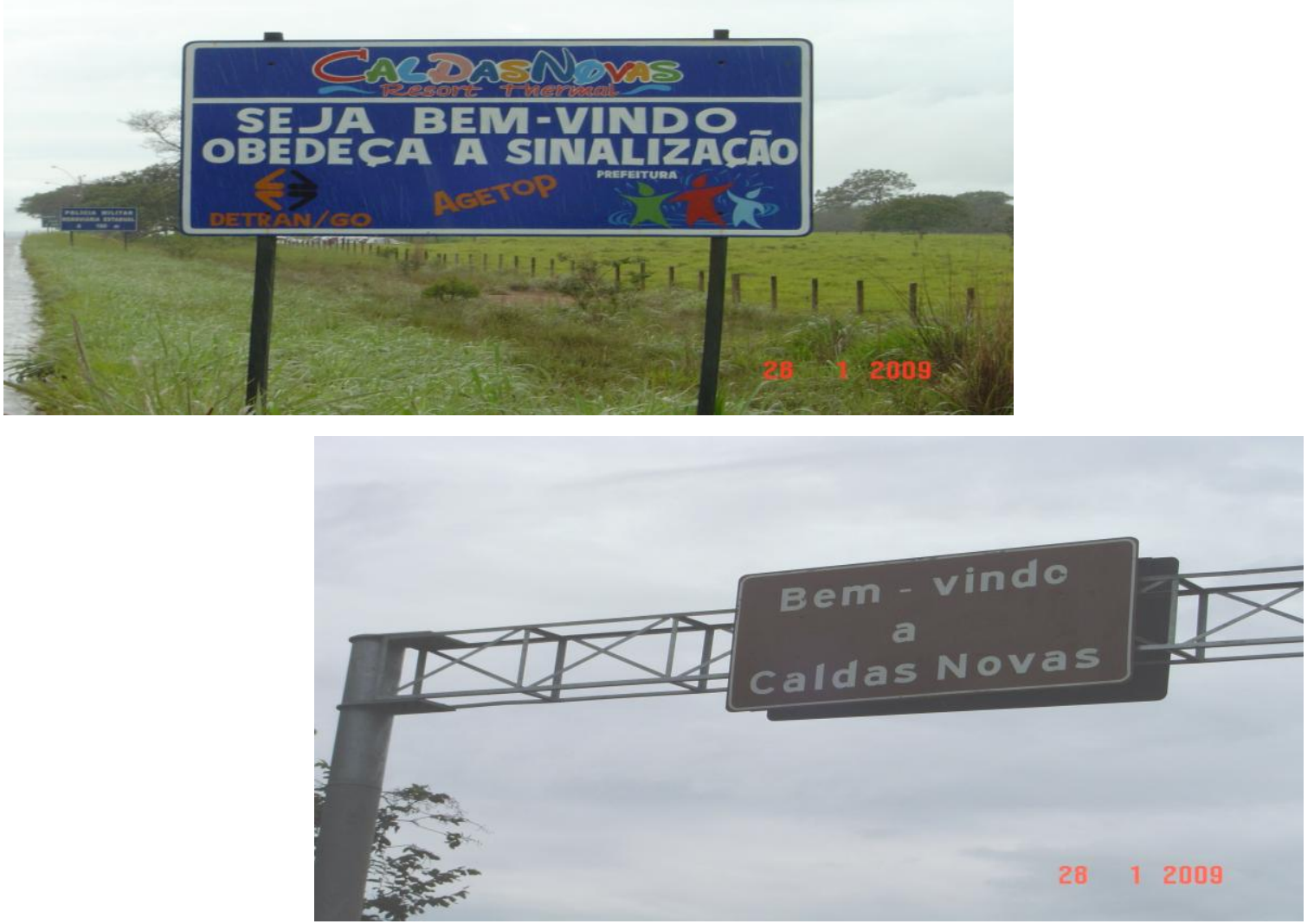

Ilustrações 9 e10. Placas rodoviárias na entrada da cidade. Fotos: Patrícia Leal, janeiro 2009. 
O posto da Policia Militar Rodoviária, em forma de chalé, e o monumento ás águas são as poucas indicações dos atrativos turísticos da cidade.

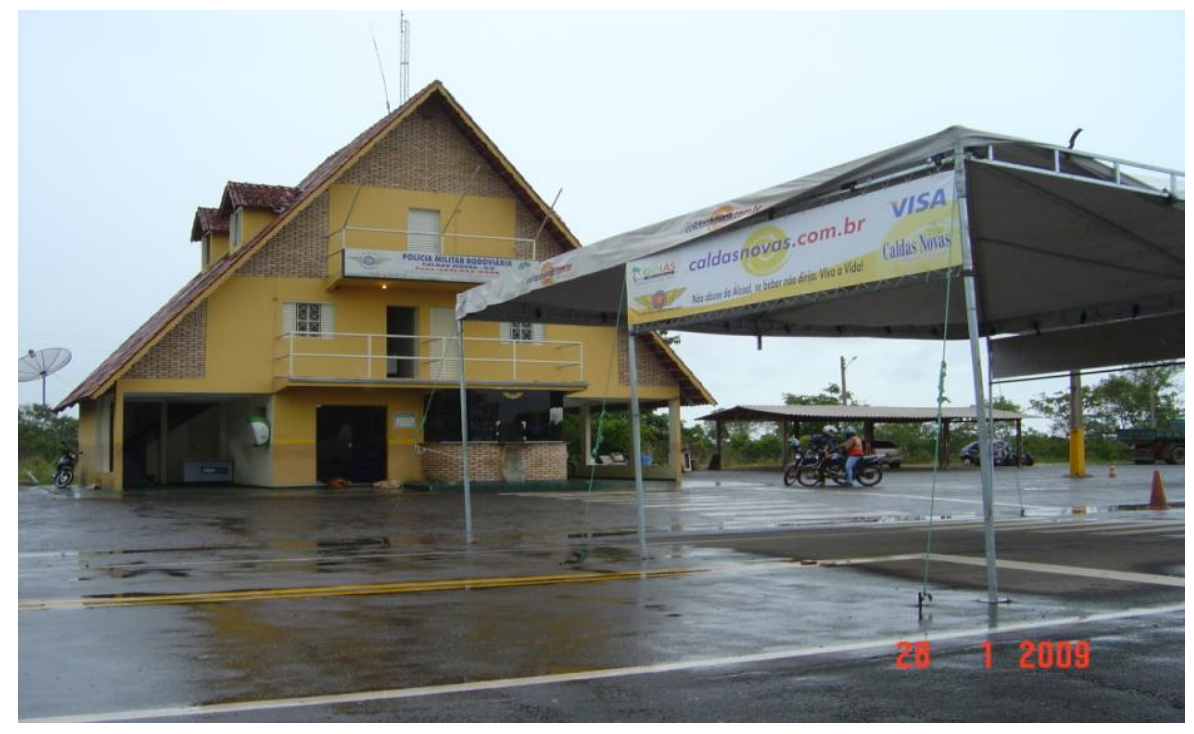

Ilustração 11. Posto da Polícia Militar Rodoviária.

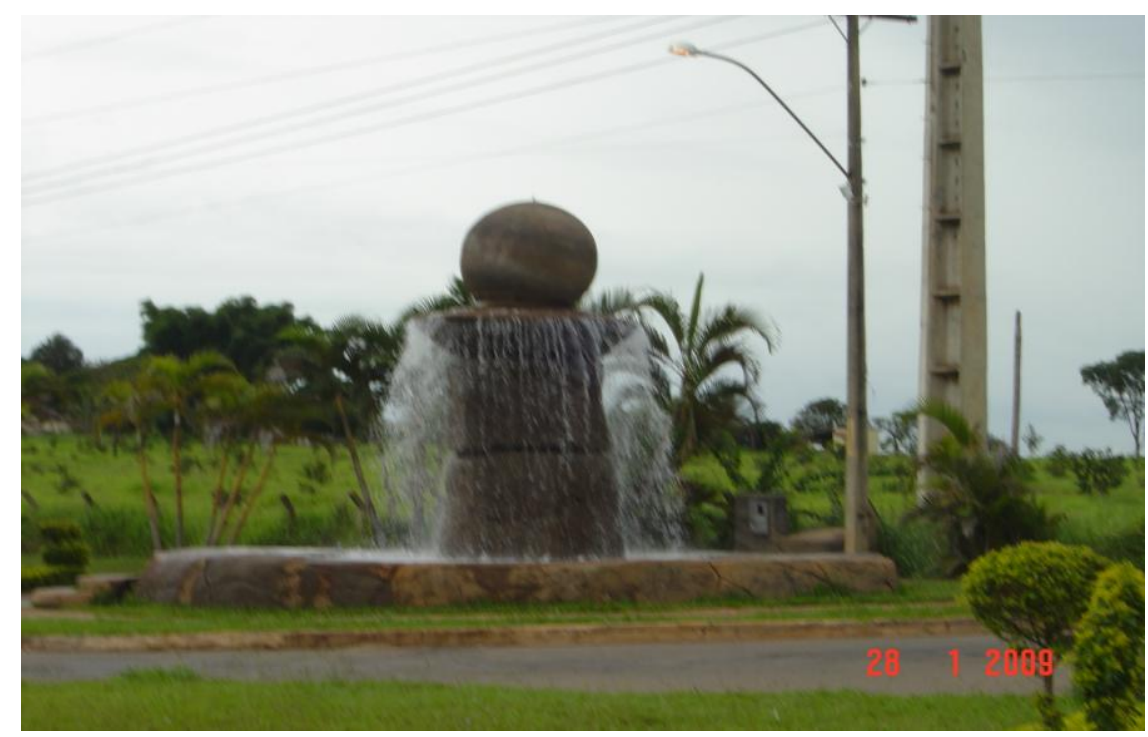

Ilustração 12. Monumento às águas, na entrada da cidade.

Fotos: Patrícia Leal, janeiro 2009 
Outro ponto que chama a atenção é a falta de placas informativas sobre a localização de alguns dos patrimônios históricos da cidade como é o caso do Casarão, da casa de Martim Coelho e do Balneário Municipal. Já outros atrativos turísticos como a Lagoa Quente e o Lago Represa do Corumbá, são amplamente divulgados.

Com o crescimento da cidade, as estreitas ruas de Caldas Novas tornaram-se pequenas para os enormes ônibus de turismo. Até o ano de 2005, a rodoviária para os ônibus intermunicipais e interestaduais era localizada perto dos pequenos hotéis existentes na Rua Orozimbo Neto.

Quando houve a inauguração da nova rodoviária, localizada na parte superior da cidade, os ônibus de turismo passaram a não mais circular pela cidade, o que é importante para a preservação das ruas e diminuição da poluição do ar.

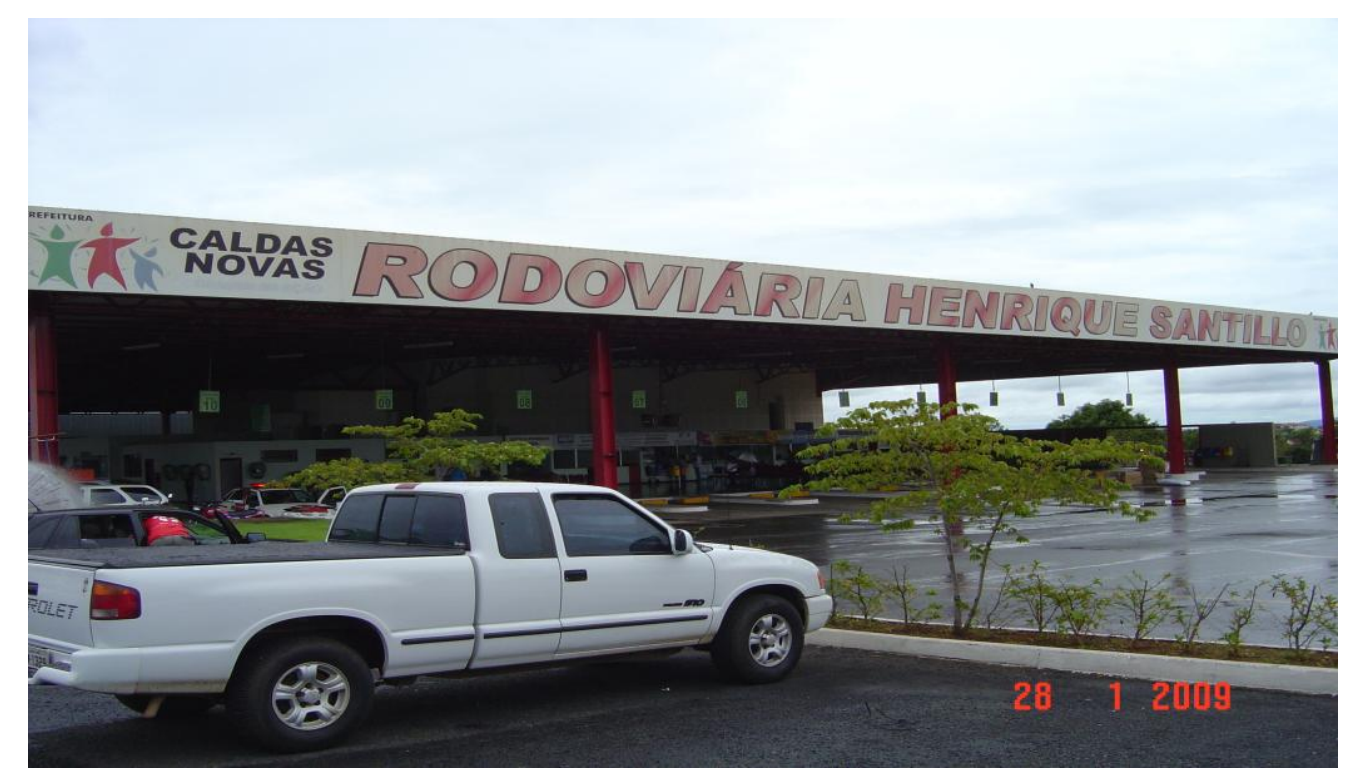

Ilustração 13. Rodoviária Henrique Santillo.

Foto: Patrícia Leal, janeiro 2009. 
Contudo, em lugar da antiga rodoviária, foi erguida uma praça em setembro de 2007. Esta praça não possui uma única referência a sua antiga situação. É lamentável, pois todo crescimento tem seu inicio em algo simples, como era a antiga rodoviária.

A certeza de que muitas pessoas hoje, passam pela praça e lembram - se das chegadas e saídas que lá aconteciam, é notória. Lembranças boas ou ruins, mas lembranças, que a geração futura desconhecerá por falta de lembrança do poder público.

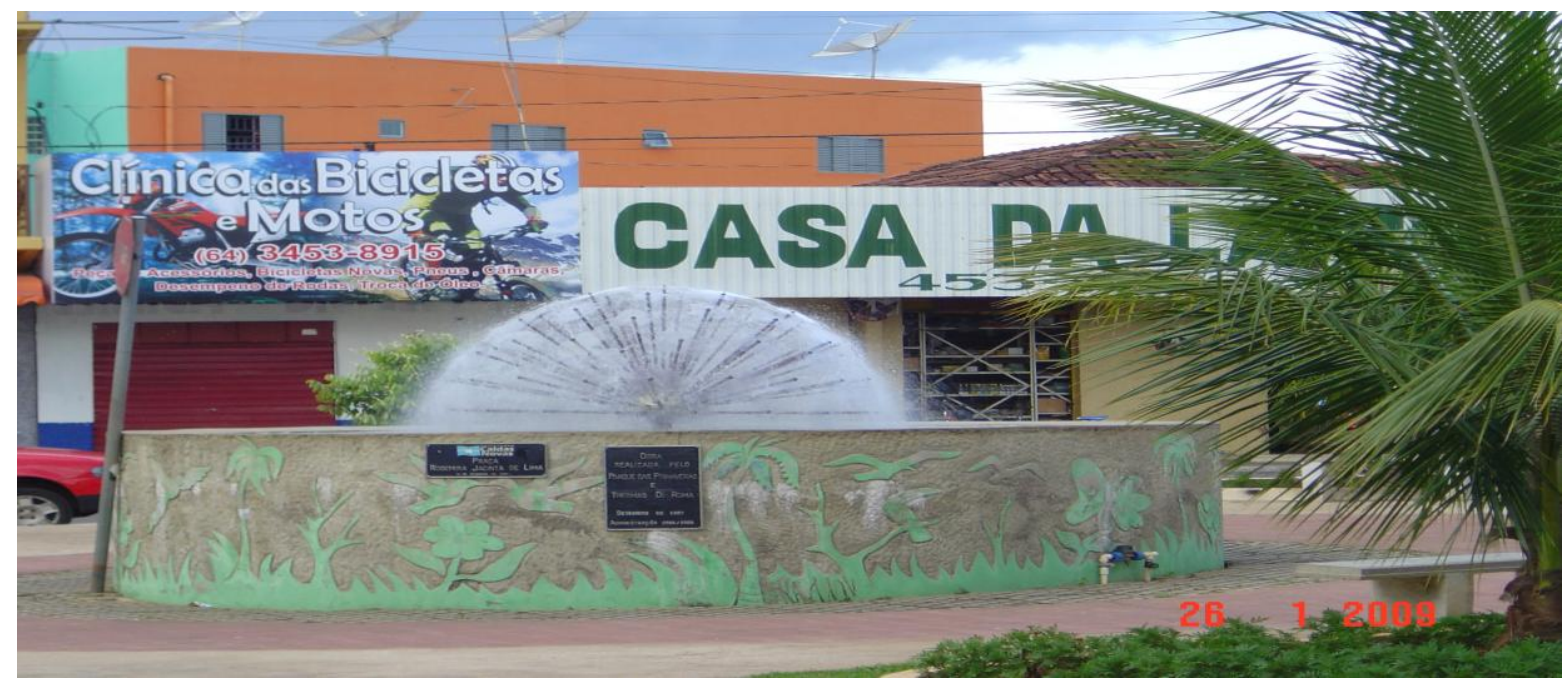

Ilustração 14. Praça Rosemira Jacinta de Lima, antiga rodoviária.

Foto: Patrícia Leal, janeiro, 2009.

No que se refere aos ônibus urbanos, não há uma rodoviária a ser utilizada pela população local e o trânsito, nos últimos anos, tornou-se caótico, principalmente no centro da cidade, durante os períodos de alta temporada.

Estacionamento é algo inexistente, e acontece um fenômeno bastante interessante: as antigas bicicletas, meio de transporte da comunidade local até pouco tempo, foram trocadas por motocicletas que competem com os carros dos turistas e da população tanto por vagas, quanto no trânsito. 
A cidade de Caldas Novas possui apenas um hospital de pequeno porte, para dar assistência médica a comunidade local e aos turistas.

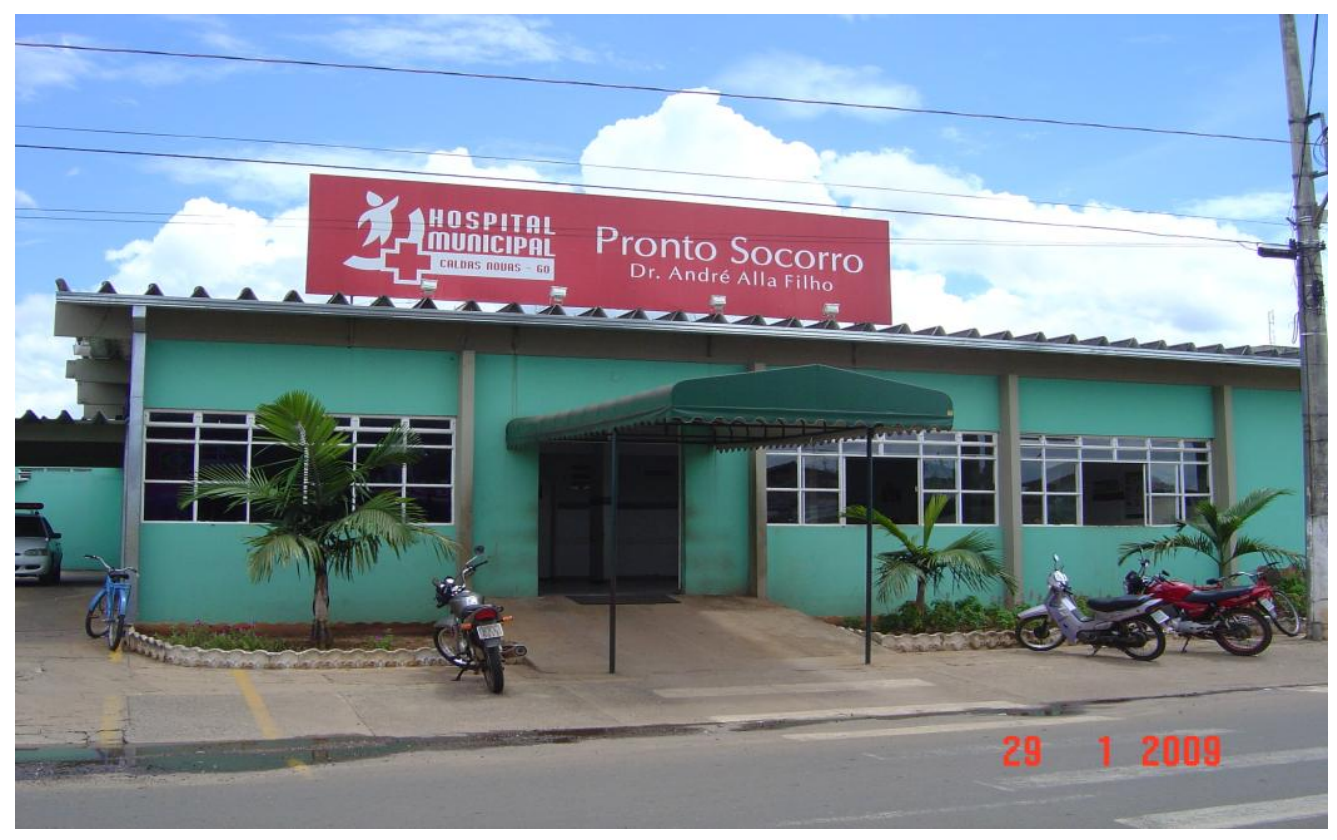

Ilustração 15. Hospital Dr. André Alla Filho.

Foto: Patrícia Leal, janeiro 2009.

A segurança da cidade, entretanto, é feita pelo distrito policial chefiado pelo delegado, Dr. Lanivaldo José Mendes. Em conversa, o Dr. Lanivaldo informou que os problemas mais comuns são brigas familiares promovidas pelo excesso de álcool e pequenos furtos por drogas.

Outro ponto levantado pelo Dr. Lanivaldo é a falta de opções de lazer da população local. A cidade não possui um teatro, e apenas uma sala de cinema está aberta à população. A Feira do Luar, acontecimento dos finais de semana fica completamente congestionada durante os períodos de temporada. Por estar localizada em espaço muito reduzido também não possui local para estacionamento de veículos. 
A Feira do Luar oferece comidas típicas e artesanato local e representa um atrativo tanto para os turistas, quanto para a comunidade local que por esta razão, necessita de uma maior atenção das autoridades.

Segundo o Dr. Lanivaldo, existe a necessidade de se criar uma festa tradicional para cidade, atraindo assim, turistas durante o período de baixa temporada, pois a tentativa que atualmente está acontecendo tem trazido problemas à cidade. De acordo com informações da Secretaria de Comunicações de Caldas Novas, os jovens que procuram à cidade levados pela oportunidade de assistir a shows, não utilizam os hotéis, dormindo em seus próprios carros e transformando as praças em banheiros públicos.

Outra idéia lançada por ele é a de uma maior união dos comerciantes locais para maior divulgação dos produtos da cidade.

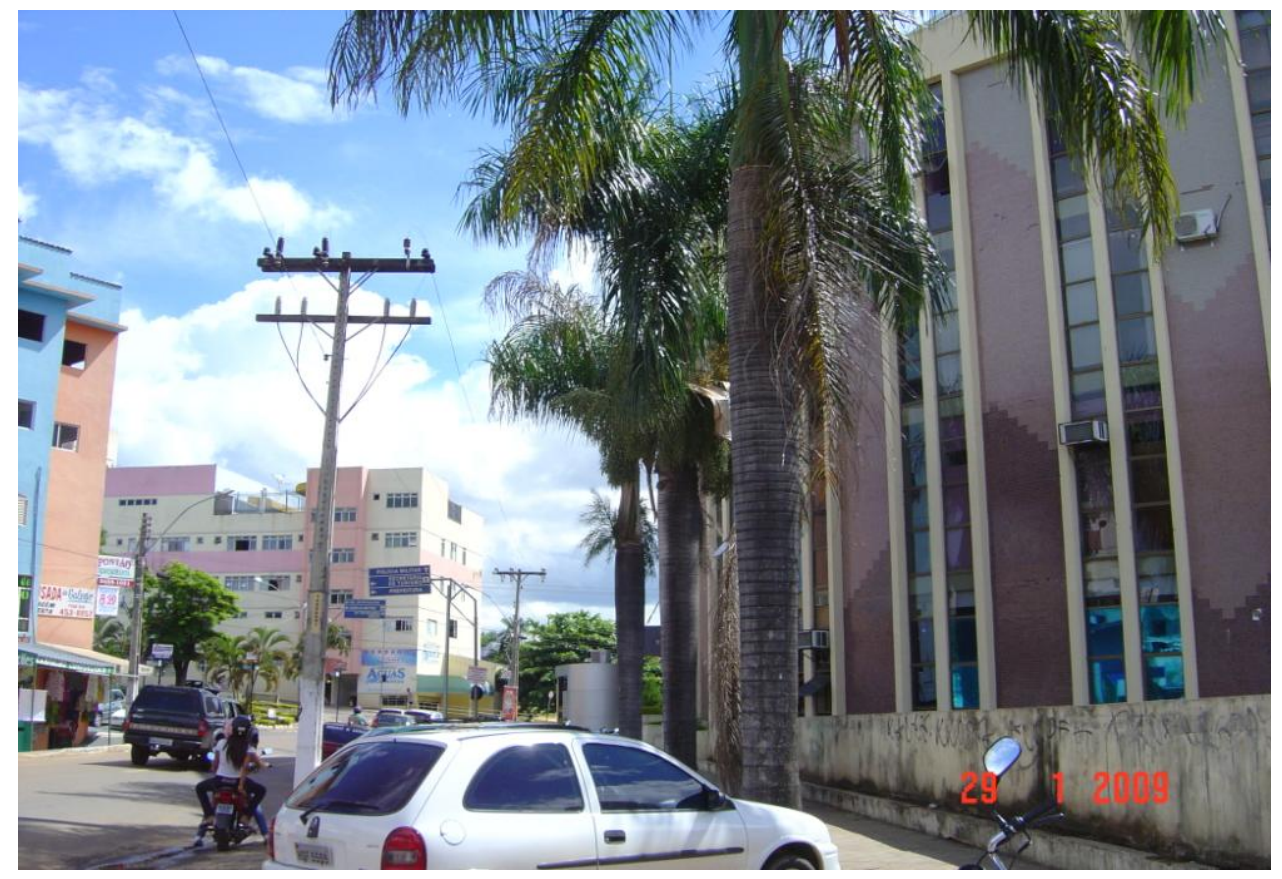

Ilustração 16. Á direita, vista lateral de um dos shoppings da cidade.

Foto: Patrícia Leal, janeiro 2009. 
Houve um crescimento da população local, devido à procura por melhores condições de vida de pessoas provenientes de diferentes partes do Brasil. Por esta razão, hoje, é comum ver nas ruas de Caldas Novas pedintes ou os conhecidos "flanelinhas", aspecto que era difícil de ocorrer durante a década de 80 , quando o comum era encontrar jovens trabalhando em restaurantes e no comércio local.

\subsubsection{Gastronomia e Divulgação dos Patrimônios Históricos}

A aculturação gastronômica pela qual a cidade está passando é perceptível a qualquer um. Os antigos restaurantes que serviam pratos típicos da região, como a tradicional sopa de galinha com milho, ou mesmo a saborosa pamonha estão desaparecendo. Em seu lugar, a típica comida paulistana, ou seja, a pizza, a picanha, ou mesmo as grandes redes de fast-food estão dominando.

Atualmente para se comer um bom peixe na telha, é preciso conhecer muito bem a cidade para descobrir em seus recantos algum restaurante caseiro algo que, para o turista em visita a cidade pela primeira vez, torna-se uma odisséia. Um centro gastronômico de nome Espaço 11, esta sendo preparado para receber pequenas lojas de restaurante de comidas rápidas. Este espaço está localizado na Rua Orozimbo Neto, a uma quadra da Prefeitura Municipal.

No que se refere à divulgação dos Patrimônios Históricos, isto quase não acontece. Nos hotéis não há qualquer menção sobre a importância destes locais para a visitação. 
Quando em visita por cidades pelo Brasil a fora, nota-se um interesse dos hotéis em divulgar, através de encartes, os atrativos turísticos locais. Porém, em Caldas Novas o maior interesse parece ser o de divulgar os atrativos da cidade do Rio Quente, cidade vizinha, e não os atrativos locais. Caldas Novas possui belíssimos locais que precisam ser "descobertos" pelos turistas. 


\subsubsection{Patrimônio Histórico - Cultural}

O primeiro patrimônio da cidade de Caldas Novas é, sem dúvida, a lagoa descoberta pela caravana de Martim Coelho de Siqueira em 1777, conhecida por Lagoa de Pirapitinga ou Lagoa Feia.

Hoje, ela encontra - se preservada dentro do clube Lagoa Termas Parque, cujo dono é o Senhor Ari Schnitz, atual Secretário de Turismo do município.

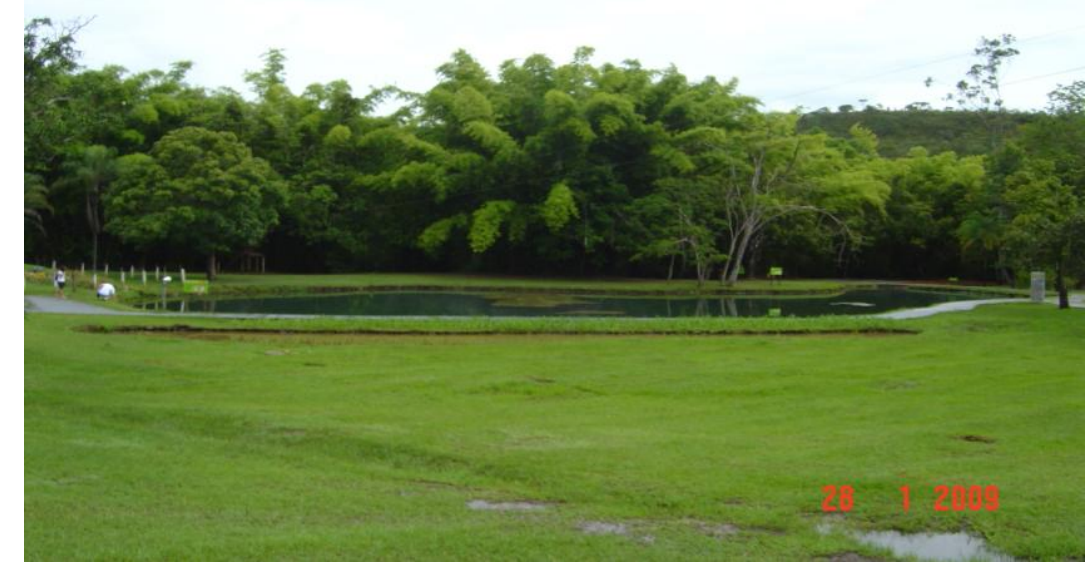

Ilustração 17. Lagoa do Pirapitinga.

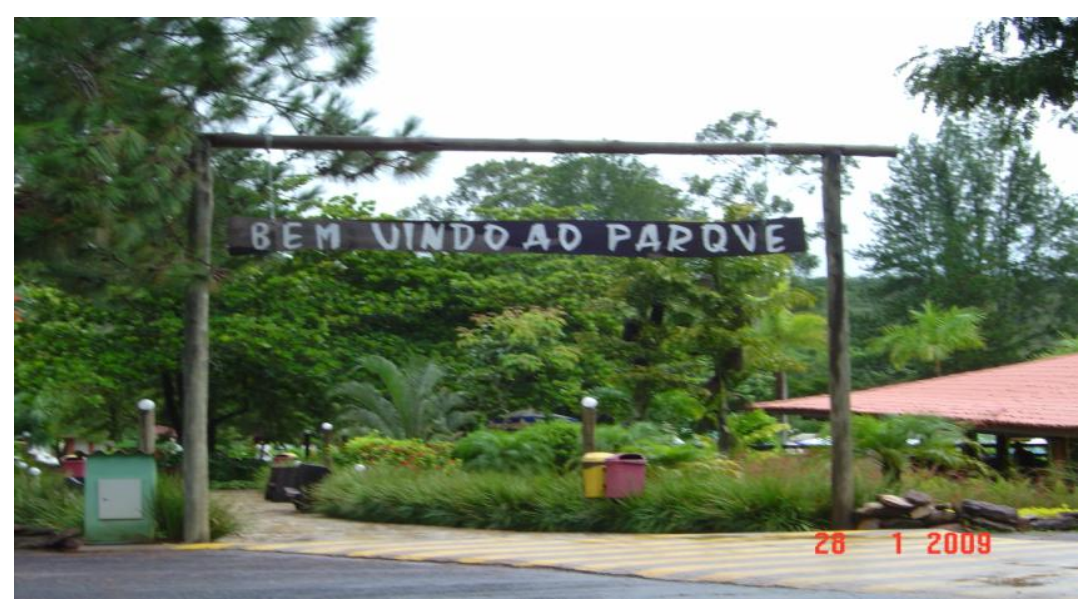

Ilustração 18. Entrada do clube Lagoa Termas Parque.

Fotos: Patrícia Leal, janeiro 2009. 
Outro patrimônio que se encontra em boas condições de preservação é a Igreja Matriz de Nossa Senhora das Dores, construída em 1850. Localizada na Praça da Matriz, suas paredes ainda retratam as construções antigas quando as vigas de sustentação das construções eram de madeira.

Tanto o Casarão quanto a casa de Martim Coelho de Siqueira, também fazem parte do acervo histórico de Caldas Novas. O Casarão tem sua construção datada de 1908 e hoje pertence à Fundação Pedro Ludovico. Apesar de desativado por algum tempo, o Casarão funciona, ocasionalmente, como centro de artesanato da região.

Já a casa de Martim Coelho de Siqueira, considerada a primeira moradia da cidade, está localizada dentro do clube do SESC (Serviço Social do Comércio).

A primeira edificação que deu origem aos banhos termais, atualmente a principal atividade turística da cidade de Caldas Novas, foi a "casa de banho" construída pelo Major Vitor Alla em 1910.

Onde hoje está erguido o Balneário Municipal, havia uma construção rústica feita de adobe e madeira, com duas banheiras, para o deleite das águas quentes pelos familiares e convidados do Major. Após sua morte, os herdeiros do Major Alla e o médico Ciro Palmerston decidem demolir a "casa de banho" e em seu lugar construir um prédio que possuía duas banheiras esmaltadas e três cimentadas, isto em 1935.

A partir desta época, o Balneário Municipal passa a ser de uso público, onde são cobrados seus banhos. Em 1940, o Balneário passa por nova reforma e ganha vinte novas banheiras. 
Atualmente o Balneário Municipal é apenas uma leve lembrança de seus tempos áureos. Para quem observa o prédio, que parece estar em reforma nos últimos três anos, a memória dos primeiros banhos termais e de sua importância para cidade é quase que inexistente, pois são poucas as pessoas que o vêem como o "primeiro hotel de Caldas Novas".

Enquanto outros acervos estão bem preservados como a Lagoa de Pirapitinga e a Matriz de Nossa Senhora das Dores, o Balneário não passa pelos mesmos cuidados. A falta de divulgação da importância do Balneário para a cidade demonstra a pouca habilidade do poder público em manter seu patrimônio vivo.

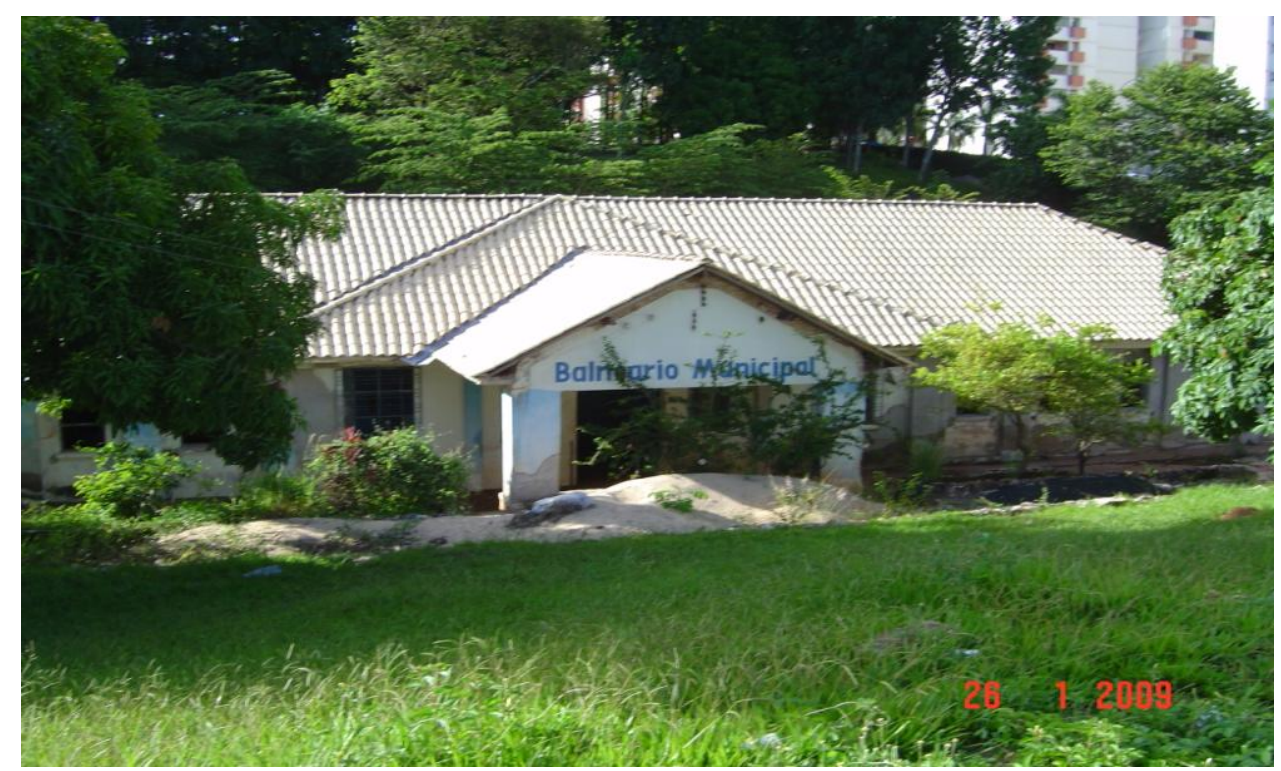

Ilustração 19. Balneário Municipal.

Foto: Patrícia Leal, janeiro de 2009. 


\subsection{O Que Está Sendo Feito}

Para fazermos uma análise das medidas que estão sendo tomadas, pela Prefeitura de Caldas Novas, para melhoria da sustentabilidade do município e de sua capacidade turística, faremos um breve comentário sobre o Plano Diretor da cidade juntamente com as entrevistas realizadas.

O Plano Diretor compõe a Lei №. 1.118/03 de 14 de abril de 2003, a qual também dispõe sobre Política Urbana. No Artigo 5ำ Plano Diretor é descrito como instrumento básico de Planejamento Urbano e Ambiental que faz parte das políticas municipais. Sendo composto de normas que são estabelecidas em Leis Municipais, Planos de Ação, e Diretrizes, seu conteúdo abrange:

- Delimitação do perímetro urbano, onde estabelece as áreas urbanas e rurais, bem como suas atividades;

- Normatização do parcelamento do solo; das edificações, através do Código de Obras; dos procedimentos para vivência e higiene, através do Código de Posturas; dos parâmetros para a preservação, recuperação e conservação do Meio Ambiente pelo Código de Meio Ambiente;

- Definição da política urbana ambiental, e das idéias básicas para o planejamento e desenvolvimento sócio-econômico.

\section{Em suas Diretrizes Gerais, PDCN coloca que:}

Uma das funções mais importantes, se não a mais, do Plano Diretor é o gerenciamento territorial. A ocupação urbana é responsável pelo desperdício de recursos públicos, de recursos naturais e tempo humano. A mercantilização livre e a especulação imobiliária em Caldas Novas são responsáveis por grande parte dos problemas da cidade.: excesso de loteamentos, ocupação esparsa, infra-estrutura urbana insuficiente e cara, loteamentos em áreas inadequadas provocando erosões e prejudicando a recarga dos lençóis aqüíferos.

(PDCN, 2003, p. 29). 
Com relação ao Perímetro Urbano, o PDCN coloca que este se encontra totalmente incorreto. O planejamento de um novo perímetro deve privilegiar os loteamentos regulares. Por tratar-se de um trabalho realizado a longo prazo, o resultado será a melhoria da qualidade de vida da população local.

No que se refere às edificações, o Código de Obras e Edificações de Caldas Novas foi orientado a atender as condições de conforto térmico, salubridade e economia do consumo de energia elétrica, proporcionando assim, uma melhor qualidade de vida.

Com o Secretário de Obras, Senhor Ciro Tomé Pereira, foram obtidas informações sobre medidas como, por exemplo, a de que projeção de prédios residenciais não poderá ultrapassar 13 andares e que terrenos de $360 \mathrm{~m}^{2}$ estariam sendo desmembrados. Contudo, houve o questionado de que em lugar de uma residência com 10 moradores estariam residindo, em uma proporção de 2 apartamentos por andar, com 05 moradores cada, 130 pessoas e que isto poderia trazer problemas de infra-estrutura. Como resposta foi colocado que as medidas tomadas foram aprovadas pelo PDCN de 2007.

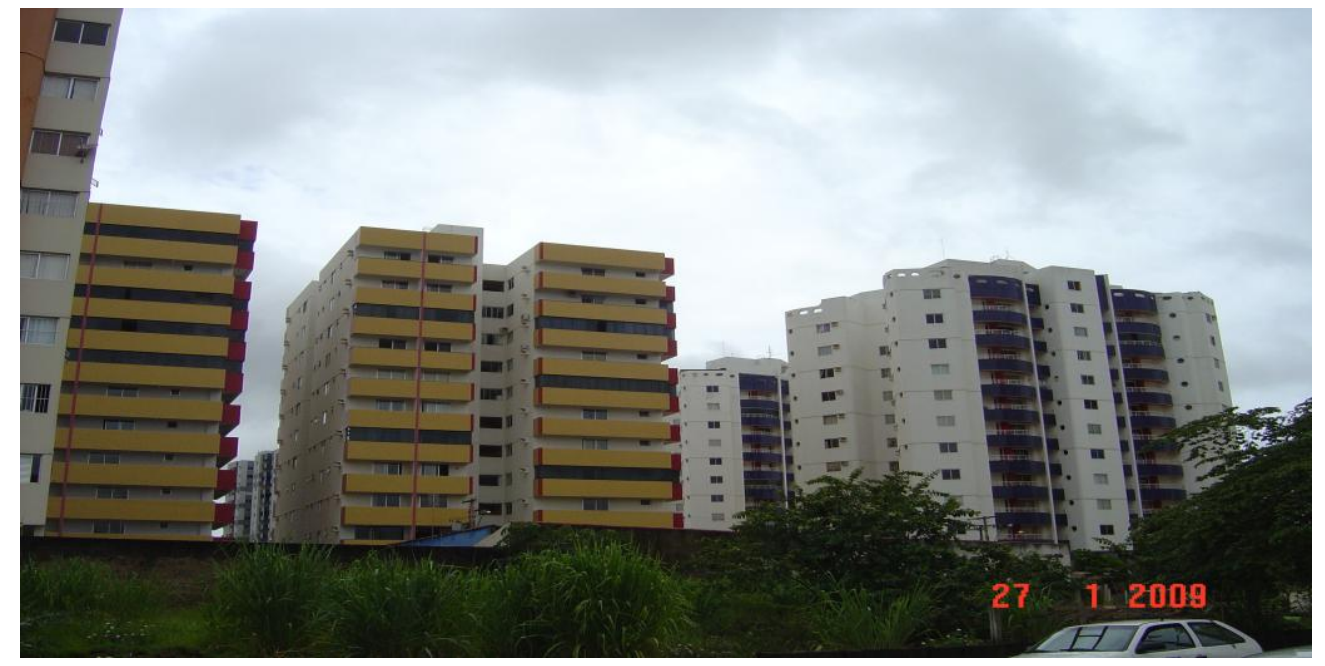

Ilustração 20. Prédios que se misturam aos hotéis.

Foto: Patrícia Leal, janeiro 2009. 
Outro ponto levantado foi a necessidade de desafogar o centro de Caldas Novas. Segundo o Senhor Ciro, medidas como estacionamento em áreas verdes e um planejamento estratégico sobre o trânsito consta também do PDCN 2007.

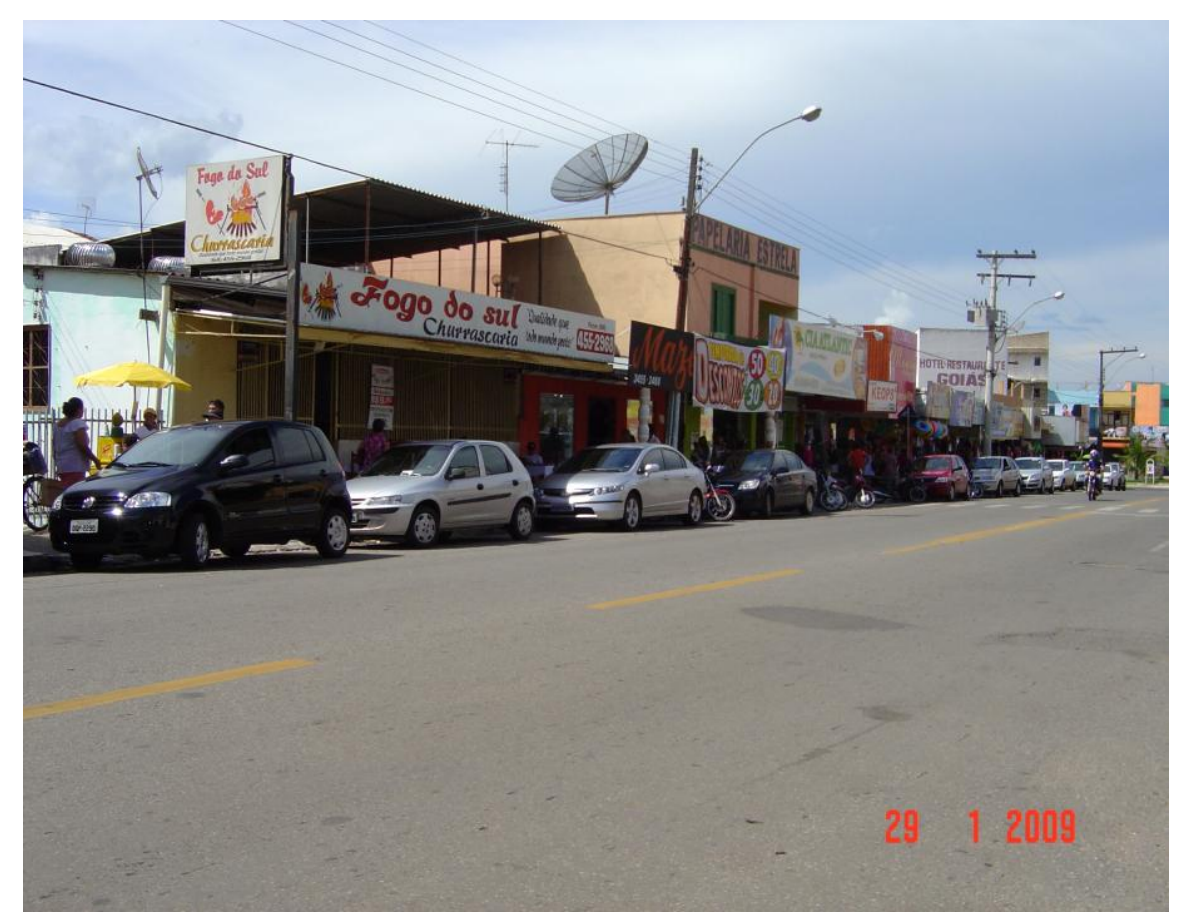

Ilustração 21. Centro da cidade de Caldas Novas.

Foto: Patrícia Leal, janeiro 2009.

Outro ponto importante do PDCN é a criação da Zona de Proteção Hídrica que propõe a preservação hídrica e a recarga das fontes aqüíferas que fazem parte do sistema hidrotermal de Caldas Novas. Para que não haja dano a este sistema, a cota limite estabelecida para ocupação humana é de $750 \mathrm{~m}$, demonstrada através de estudos técnicos realizados sobre o assunto. Além da zona de proteção aqüífera, o PDCN relata a necessidade de criação da APA da bacia do Ribeirão Pirapetinga. 


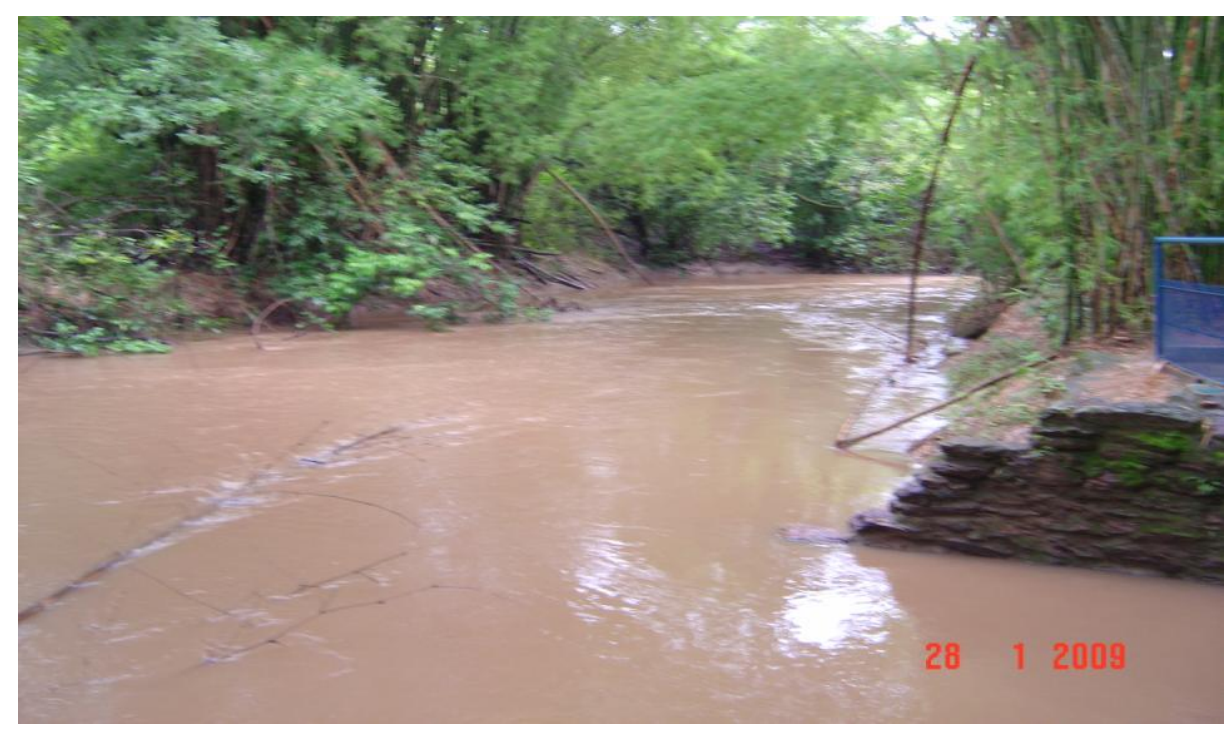

Ilustração 22. Ribeirão Pirapitinga.

Foto: Patrícia Leal, janeiro 2009.

Para o PDCN, o sistema hidrotemal segue diretrizes organizadas pelos geólogos Fernando Gambier e Fábio Haesbaert, que foram colaboradores voluntários para este Plano Diretor. As diretrizes que chamaram maior atenção foram as seguintes:

- Incentivo a implantação de um sistema de tratamento de esgoto, de novas lagoas de tratamento e reciclagem de água termal;

- Criação de uma faixa de proteção nas cercanias da Serra de Caldas, com a intenção de preservar a região contra as ocupações urbanas e ações predatórias, incluindo a Zona de Proteção Hídrica;

- Priorizar a água de poços tubulares com temperatura igual ou superior a 25으 $\mathrm{C}$ para uso restrito dos balneários;

- Procurar melhorias para o sistema hidrotermal, através de novas tecnologias para reciclagem e reaproveitamento da água de uso doméstico; 
- Desenvolver uma campanha de educação ambiental que tenha cunho efetivo e absoluto e que envolva desde a população local até os órgãos públicos e privados. Esta campanha possui o intuito de mostrar que a preservação ambiental, principalmente no que se refere ao sistema termal, é de fundamental importância para a manutenção da maior fonte de renda do município, de um mercado de trabalho atuante e do patrimônio cultural da comunidade. (PDCN, 2003, p. 34 a 38);

Além das informações obtidas pelo PDCN, de acordo com o Secretário de Obras de Caldas Novas, Sr.ำ Ciro Tomé Pereira cada balneário pode apenas utilizar dois poços.

Caso haja a necessidade de se fechar um desses poços para abertura de um outro, existe todo um procedimento legal a ser realizado, ou seja, segundo o Senhor Ciro, nenhum poço pode ser aberto ou fechado sem o conhecimento da secretaria de obras. Um dos projetos que esta secretaria possui é o de recurar os córregos da cidade de Caldas Novas.

De forma resumida, com relação ao meio ambiente, as Diretrizes Gerais tratam do cuidado com o controle da poluição, do impacto ambiental provocado por novos empreendimentos e atividades, dentre outros. Baseando-se nessas diretrizes, os planos de ação visam:

- Criar um Plano Municipal de Educação Ambiental;

- Divulgar e valorizar as particularidades ambientais da região, através de um circuito turístico rural;

- Fixas metas de redução das várias fontes de poluição;

- Recompor as matas ciliares para a preservação dos cursos d' água;

- Replanejar programas de monitoramento das nascentes; 
- Promover seminários e palestras que tenham como objetivo a sustentabilidade e a pesquisa;

- Incentivar a criação de escolas profissionalizantes, onde a educação ambiental faça parte da grade curricular;

- Controlar o zoneamento urbano no que se relaciona ao sistema de coleta e tratamento de esgoto, aterro sanitário de lixo, sistema de coleta de águas pluviais e sistema de abastecimento de água tratada.

O PDCN trata o tópico Turismo juntamente com Cultura, Esporte e Lazer. Dentre as principais Diretrizes encontram-se as que se seguem:

- Descentralizar e diversificar as atividades que envolvem o lazer, tornando-o parte importante na qualidade de vida da população;

- Integrar as identidades culturais da cidade.

Com relação à cultura, as propostas de ação que mais se assemelham as idéias desta pesquisa foram:

- A criação de um Museu da cidade que resgate a memória local e regional através de exposições, e preserve o patrimônio histórico, cultural e arquitetônico;

- Fazer um levantamento do patrimônio cultural da cidade, buscando com isso a sua valorização e subsídios, através de políticas públicas.

As Diretrizes relacionadas ao Turismo e Lazer têm algo haver com a proposta deste trabalho, pois contem a intenção de preservar e divulgar o patrimônio da cidade de Caldas Novas. 
Destacam - se as seguintes:

- Com relação à mão-de-obra:

Habilitar e qualificar mão-de-obra especializada em Turismo, como guias, recepcionistas e taxistas para prestar um melhor atendimento através de informações sobre as atrações turísticas da cidade;

> Utilizar as Universidades locais para realizar um levantamento sobre a demanda turística do município.

- Estabelecer uma sinalização para os atrativos turísticos da cidade, bem como manter em bom estado de conservação as rodovias que dão acesso ao município;

- Demonstrar à população a importância das atividades turísticas para o município, através de campanhas de conscientização;

- No que se refere aos atrativos turísticos locais, fortalece - los da seguinte maneira:

> Balneário Municipal: > restaurar prédio e equipamentos, tendo em vista a visitação pública;

$>$ divulgar as propriedades terapêuticas das águas quentes.

Casarão: > restaurar e preservar o rancho;

> Criar Centro de Tradições Goianas, Centro de Apoio ao Artesão local, assim como, calendário de exposições e atividades culturais;

$>$ Instalar um restaurante de comidas típicas para resgatar as tradições culinárias da região. 
Lago de Corumbá e Ribeirão Pirapetinga:

> Estimular a prática de esportes náuticos;

> Criar área de Camping próxima às margens do lago.

Parque Estadual da Serra de Caldas Novas:

\author{
$>$ Construir ciclovias e criar \\ roteiros ciclísticos para os \\ finais de semana e feriados; \\ > Implantar programas com \\ vistas a desenvolver o \\ ecoturismo.
}

Feira do Luar: > Divulgar os produtos existentes na feira como o artesanato local e pratos típicos.

Segundo o Senhor Ari Schnitz, Secretário de Turismo do município de Caldas Novas, a secretaria possui um planejamento estratégico para o ano de 2009. Neste planejamento estão contidas ações rápidas como o alargamento da pista de pouso do aeroporto da cidade, Nelson Ribeiro Guimarães, realizada no final do ano de 2008. Esta obra visa à implantação de vôos de carreira onde Caldas Novas seja parte de um trajeto das linhas aéreas, ou seja, uma escala ou mesmo o ponto final de um trajeto maior. Isto porque hoje, somente vôos fretados pousam na cidade. 
Outra ação rápida mencionadas pelo Secretário é a integração turística entre Brasília - Caldas Novas, que já é realizada pela Brasíliatur com a cidade de Pirenópolis e a Chapada dos Veadeiros (anexo b e c).

Esta integração tem o propósito de levar os turistas que visitam Brasília, a procurar atrativos turísticos em regiões próximas.

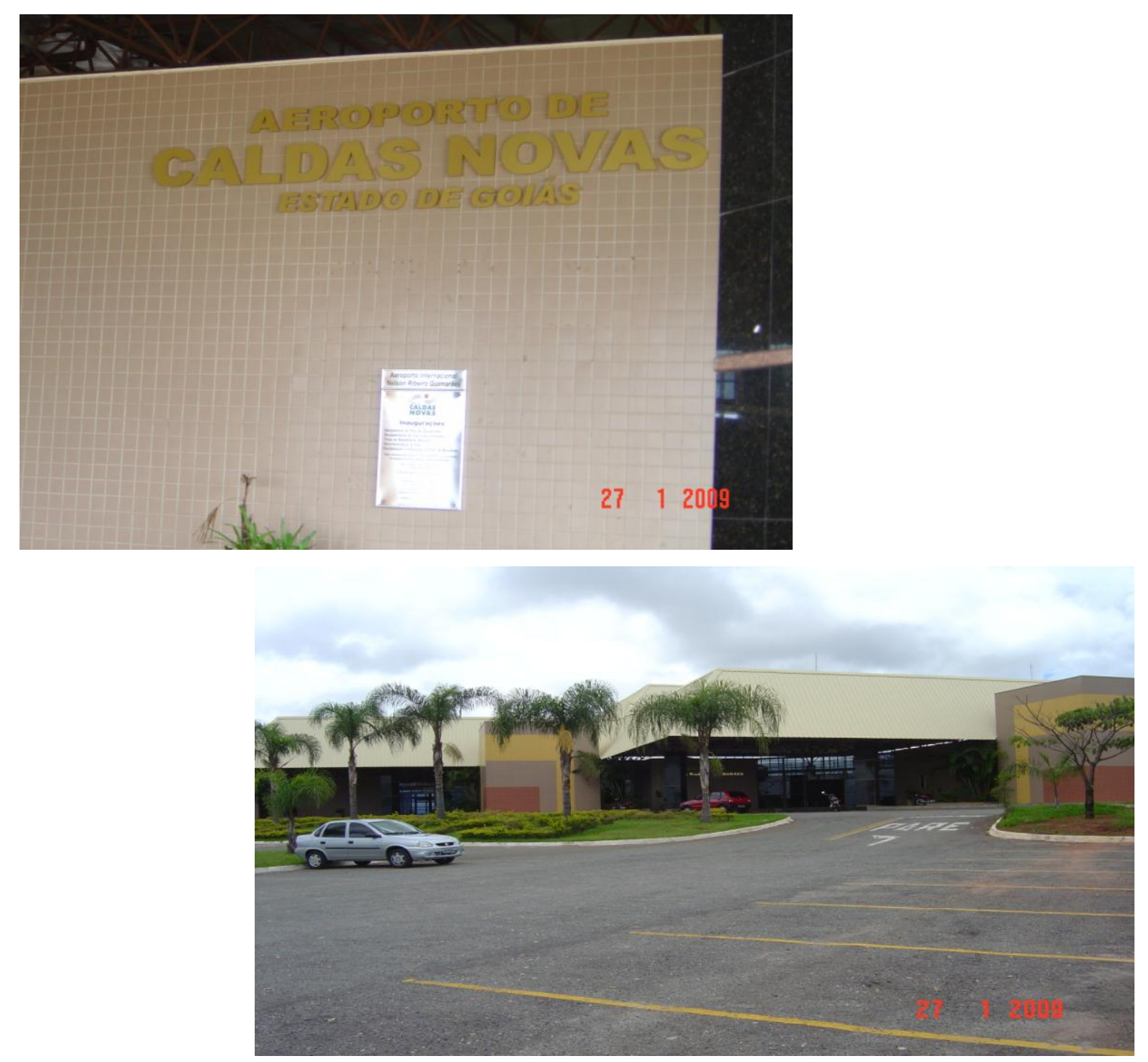

Ilustração 23 e 24: Aeroporto de Caldas Novas.

Foto: Patrícia Leal, janeiro 2009. 
3.3.1 - Tabela 1 - Gargalos do Turismo

\begin{tabular}{|c|c|c|}
\hline ASPECTO & IMPACTOS & DIRETRIZES \\
\hline Mudanças & $\begin{array}{l}\text { Alteração da } \\
\text { Paisagem }\end{array}$ & $\begin{array}{l}\text { > Planejar um novo perímetro urbano, } \\
\text { onde se privilegia os lotes regulares; } \\
>\text { Normatizar o parcelamento do solo e } \\
\text { das edificações, através do Código de } \\
\text { Obras. }\end{array}$ \\
\hline & Infra-estrutura & $\begin{array}{l}\text { > Desafogar o centro da cidade; } \\
\text { >Normatizar os procedimentos de vivência } \\
\text { e higiene, através do Código de Posturas; } \\
\text { > Criar a Zona de Proteção Hídrica e a } \\
\text { APA da Bacia do Ribeirão Pirapitinga; } \\
\text { > Recaregar as fontes aqüíferas, que } \\
\text { fazem parte do sistema hidrotermal; } \\
\text { > Incentivar a implantação de um sistema } \\
\text { de tratamento de esgoto, de novas lagoas } \\
\text { de tratamento e reciclagem de água } \\
\text { termal; } \\
>\text { Criar uma faixa de proteção nas } \\
\text { cercanias da Serra de Caldas, com a } \\
\text { intenção de preservar a região contra as } \\
\text { ocupações urbanas e ações predatórias, } \\
\text { incluindo a Zona de Proteção Hídrica; } \\
\text { > Priorizar a água de poços tubulares com } \\
\text { temperatura igual ou superior a 25ํㅡ C para } \\
\text { uso restrito dos balneários; } \\
>\text { Procurar melhorias para o sistema } \\
\text { hidrotermal, através de novas tecnologias } \\
\text { para reciclagem e reaproveitamento da } \\
\text { água de uso doméstico. }\end{array}$ \\
\hline
\end{tabular}




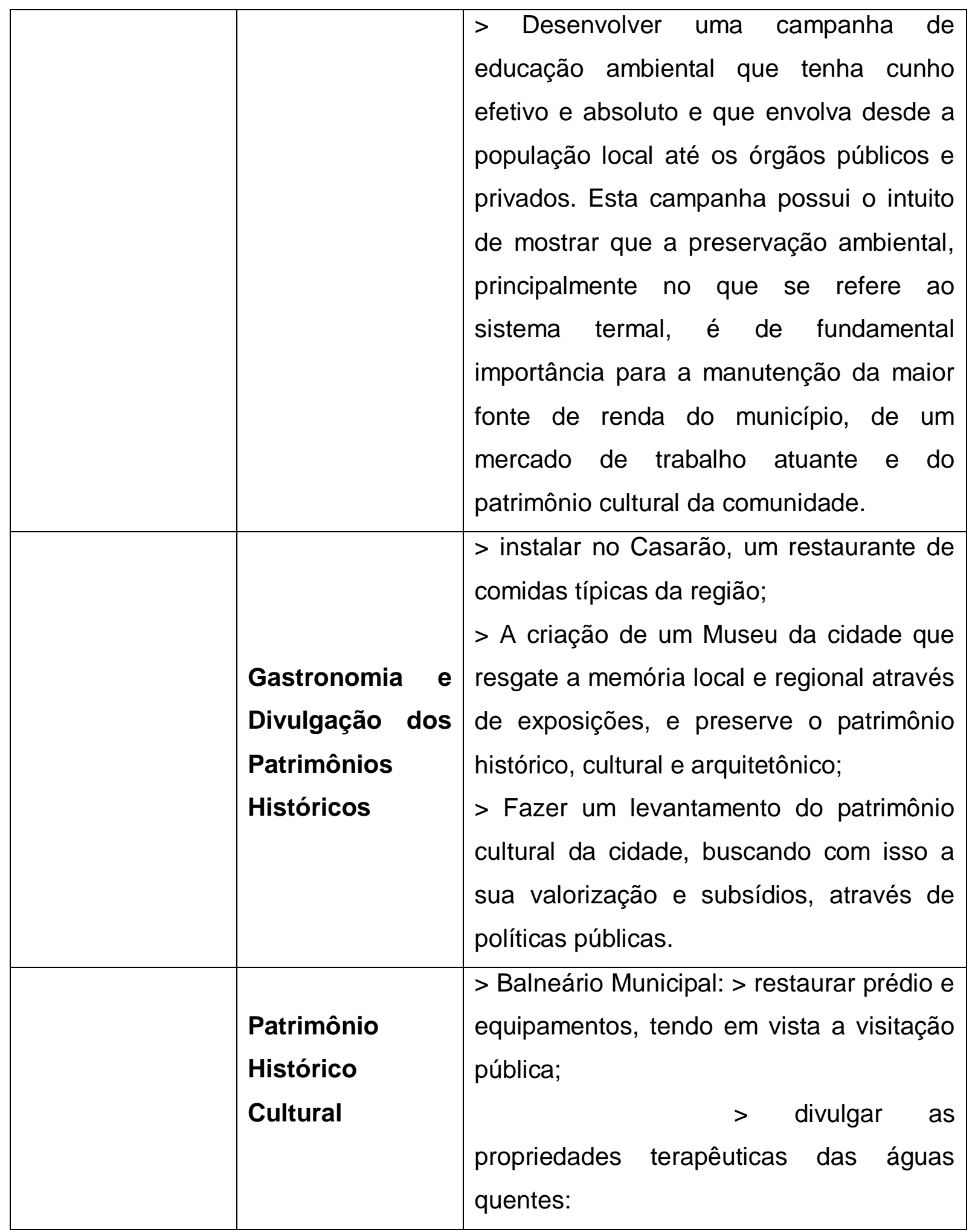




\begin{tabular}{|l|l|}
\hline & $\begin{array}{l}\text { Casarão: > restaurar e preservar o } \\
\text { rancho; } \\
\text { Goianas, Centro de Apoio ao Artesão } \\
\text { local, assim como calendário de } \\
\text { exposições e atividades culturais. }\end{array}$ \\
\hline
\end{tabular}




\section{4 - Análise de Dados}

Atualmente, a cidade de Caldas Novas é mais conhecida por suas águas termais do que por seus atrativos históricos. Por esta razão, o crescimento da cidade está acontecendo mais na área imobiliária, do que na de preservação do patrimônio histórico cultural. Isto está bem demonstrado através do crescimento desordenado e na falta de divulgação e preservação de seus patrimônios.

A preservação do patrimônio está ancorada a dois fundamentos básicos: a Sustentabilidade e a Memória. O primeiro fundamento visa atender as necessidades do monumento sem descaracterizar o patrimônio. Para isto, utiliza recursos como a Gestão Participativa, a Educação do Turista e o mais importante deles: o Planejamento Sustentável. Este, além de evitar prejuízos futuros, soluciona problemas com mais facilidade. Já o segundo fundamento, a Memória, trata das tradições de um povo. Sem a preservação da Memória, não há como manter viva a identidade cultural dos grupos sociais.

A História da cidade de Caldas Novas tem se início em 1722, quando o filho de Anhanguera, Bartolomeu Bueno da Silva Filho, chegou a Serra de Caldas à procura de ouro. Hoje, é onde está localizada a cidade do Rio Quente. Em 1777, a caravana de Martin Coelho de Siqueira descobre a Lagoa do Pirapitinga. Em 1788, Martin Coelho ganha uma gleba de terra e dá ao novo povoado o nome de Caldas Novas. Em 1911, a cidade passa a ter status de município e em 1988, a cidade do Rio Quente passa a ser um município independente.

Hoje, Caldas Novas está localizada em uma área de 1.600 km, com uma população em torno de 65.000 habitantes. Tanto esta população quanto os turistas que procuram à cidade em período de temporada ou em finais de semana 
estão convivendo com esqueletos de edificações abandonados, hotéis cobertos pelo mato, assim como, prédios com uma média de 10 andares. $O$ problema é que, além destes prédios estarem descaracterizando a cidade e empurrando a população para o seu interior, a rede de saneamento básico continua a mesma. Isto sem mencionar o contingente policial, com apenas uma delegacia e um hospital, que na realidade é um pronto-socorro.

A mudança da rodoviária para a parte de cima da cidade trouxe os benefícios de auxiliar na despoluição do ar e desafogar um pouco o trânsito, tão confuso, da cidade. Contudo, a antiga rodoviária localizava-se no centro da cidade, perto da maioria dos hotéis. Hoje, depende-se de taxistas para se chegar aos hotéis, e estes costumam cobrar um valor fixo, principalmente se o turista estiver com bagagem. Nas instalações da nova rodoviária, encontra-se o Centro de Informação para o Turista. O problema deste Centro é que as informações por ele divulgadas são panfletos de hotéis, inclusive da cidade do Rio Quente, e as pessoas que lá trabalham poderiam, com certeza, passar por um treinamento de como receber bem o turista.

A comunidade local sente falta de uma maior divulgação do fato de Caldas Novas ser a maior estância hidrotermal do mundo. Além desta divulgação, a cidade possui poucas opções de entretenimento. Os shows que acontecem, atualmente, só têm trazido "dor de cabeça" para a população e para os comerciantes, pois este público traz consigo seu alimento e nada consome da cidade. Isto sem falar dos períodos de Semana Santa e carnaval, quando a população local de maior renda "foge" para não enfrentar o caos em que a cidade mergulha com seu transito desordenado, a falta de estacionamento e a poluição sonora que impera principalmente, no centro da cidade.

A gastronomia é algo que tem sofrido aculturação nestes últimos anos. As tradicionais pamonharias estão sendo substituídas por restaurantes fast- 
food. O tradicional "peixe na telha", é prato raro nos atuais restaurantes da cidade. Para quem freqüenta a cidade, os restaurantes de comidas típicas acabam sendo descobertos. Para o turista "de primeira viagem" resta um bom sandwich ou quem sabe, uma pizza calabresa.

O Patrimônio Histórico Cultural de Caldas Novas se encontra em situação complicada. Enquanto a Lagoa do Pirapitinga e a Igreja de Nossa Senhora das Dores estão preservados, o Balneário Municipal não está aberto à visitação. Quem passa por perto, acredita que este patrimônio está em reforma. Contudo, não se vê nenhum trabalhador no local.

Para se chegar aos outros patrimônios da cidade como o Casarão e a Casa da Fazenda, que foi a primeira residência do, então, povoado de Caldas Novas, é quase como uma "caça ao tesouro". Não há uma placa sequer que indique a direção onde, por exemplo, está localizado o Casarão e quanto a Casa da Fazenda, de acordo com o site CALDAS NOVAS: Brasil - O maior manancial hidrotermal do mundo, encontra-se dentro do Clube do SESC. A impossibilidade de fotografar, para este estudo, este dois patrimônios se deu a partir do momento que não se conseguiu encontrar o Casarão e para se adentrar ao Clube do Sesc, haveria a necessidade de se adquirir um convite, com a ciência de um sócio.

A reforma, que transformou a praça onde está localizada a Igreja de Nossa Senhora das Dores, levou consigo o coreto que lá existia. Os responsáveis por esta reforma contribuíram, juntamente como aqueles que estão tirando as casas e em seu lugar construindo gigantescos prédios, para descaracterizar a cidade, que tinha "um certo ar bucólico" e agora não consegue administrar seu patrimônio.

O PDCN possui diretrizes que visam solucionar os maiores problemas enfrentados pela cidade nos dias atuais. Estas diretrizes estão relacionadas tanto 
a infra-estrutura da cidade quanto ao preparo da mão-de-obra relacionada ao turismo, além da preocupação de se preservar o patrimônio. Porém, um plano que é de 2003, até agora, fez muito pouco ao que se propõe.

É importante que o Poder Público e os empresários da cidade definam que tipo de público esperam receber na cidade. Será que as pessoas que procuram à cidade em época de shows, Semana Santa e Carnaval que não movimentam a renda do município e que transformam as praças em banheiros públicos é o público alvo do turismo de Caldas Novas? Ou será que a cidade prefere receber um turista que procura por suas águas termais para relaxar, suas belas matas para a prática do ecoturismo ou mesmo seus patrimônios históricos para conhecer um pouco mais da História do Brasil? Portanto é necessário que sejam postos em prática toda a teoria já vigente para que a cidade de Caldas Novas volte a ser um lugar onde patrimônios são preservados. 


\section{CONSIDERAÇÔES FINAIS}

A cidade de Caldas Novas possui, além de suas águas termais, um acervo histórico que necessita de atenção por parte do poder público e da comunidade local. Por tratar-se de uma localidade com características bem específicas, a maior estância hidrotermal do planeta requer uma maior divulgação de seus patrimônios.

A idéia de realizar um trabalho de pesquisa que abordasse o tema das transformações pela qual a cidade está passando nas últimas décadas, surgiu da preocupação em preservar o patrimônio e a memória histórica que esta região possui.

Um trecho de um parágrafo do capítulo O Planejamento Turístico: Conceitos Básico, contido no livro Turismo e Planejamento Sustentável - A proteção do Meio Ambiente da Professora Dóris Rushmann foi o que fomentou a intenção por esta pesquisa. Este trecho trata do seguinte:

\footnotetext{
Nesse estágio pode-se visualizar a transformação da localidade, que constitui o inicio da sua extinção como atrativo turístico, pois a "massificação" de um recurso faz com que este perca suas qualidades e características motivadoras da vinda de turistas e portadores das sementes da própria extinção. (RUSHMANN, 2008, p.95)
}

Portanto, esta pesquisa busca resgatar a importância da cidade de Caldas Novas como patrimônio, uma vez que além de propiciar com suas águas termais as benesses para tratamentos de saúde, contem locais que trazem consigo a História deste país. 
O Turismo torna-se então, o elemento que abre as cortinas e demonstra a beleza, a importância histórica e a necessidade de preservação deste município.

A partir da análise do Plano Diretor do município de Caldas Novas, foi constatado que o Turismo relativo ao patrimônio histórico cultura, desempenha hoje, papel de maior importância para o município do que antigamente, quando este se restringia as propriedades terapêuticas das águas termais.

Com a entrevista do Secretário de Obras, Senhor Ciro Tomé Pereira, pode-se ver que medidas com relação à infra - estrutura, tanto urbana quanto turística, estão sendo providenciadas. A entrevista com o Secretário de Turismo, Sr.ำ Ari Schnitz, também demonstrou que ações em prol da melhoria e divulgação dos atrativos turísticos do município estão sendo planejadas e algumas, até sendo executadas.

Portanto, pode-se afirmar que uma tentativa de planejamento integrado está acontecendo no município. Para Rushmann:

Um dos maiores problemas dos planos de desenvolvimento turístico reside na sua falta de integração com outros programas sociais e físicos das localidades. Por isso acabam sendo empreendidos isoladamente e nem sempre atingem os objetivos propostos.

(RUSCHMANN, 2008, p 87).

O trabalho de pesquisa realizado aqui não possui uma conclusão. Planejar é um ato contínuo e aqui foi dado o primeiro passo para que a idéia de preservação e divulgação dos bens patrimoniais da cidade de Caldas Novas não fique somente no papel, como o descrito no PDCN. È muito importante que planejamentos estratégicos sejam postos em prática. 
A cidade de Caldas Novas está despontando para um desenvolvimento turístico em larga escala e necessita de um trabalho atuante tanto do poder público quanto dos empresários para preservação de seu patrimônio. De acordo com Castro Neves (2003, p.53) "Os bens patrimoniais são instrumentos importantes de identificação dos grupos sociais".

È necessário que haja um trabalho contínuo no que se relaciona a preservação do patrimônio material e imaterial de Caldas Novas, principalmente àqueles que estão se apagando como o artesanato e os pratos típicos. Por esta razão, deixamos para futuras pesquisas um acompanhamento das ações que estão sendo realizadas, bem como para àquelas que serão realizadas com este fim, ou seja, o de preservar o patrimônio da cidade de Caldas Novas.
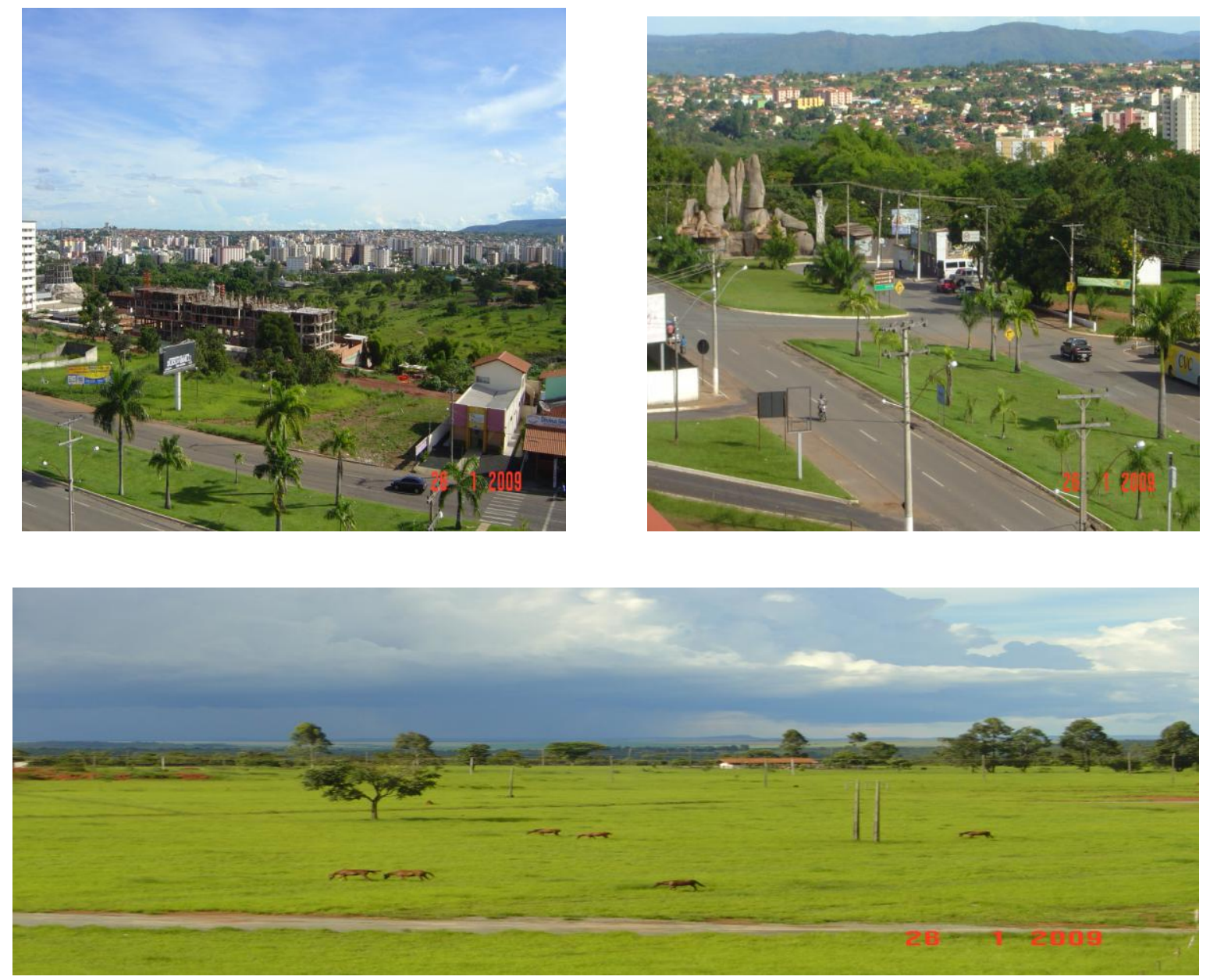

Ilustração 25,26 27: Entrada da cidade de Caldas Novas.

Foto: Patrícia Leal, janeiro de 2009. 


\section{REFERÊNCIAS}

\section{LIVROS:}

BUARQUE, Sergio C. Construindo o desenvolvimento local sustentável Metodologia de planejamento. 1. ed. Rio de Janeiro: Garamond, 2002.

CASTRO NEVES, Berenice A. de. Patrimônio Cultural e Identidades. In: MARTINS, Clerton (org.). Turismo, Cultura e Identidade. 1. ed. São Paulo: Roca, 2003: $49-61$.

FERREIRA, Ângela Mํㅡ. R. Turismo e Sustentabilidade. In: MARTINS, Clerton (org.). Turismo, Cultura e Identidade. 1. ed. São Paulo: Roca, 2003: 01 - 12.

GOFF, Jacques. História e Memória. Tradução Bernardo Leitão...[et al.] - 5 ed. Campinas, SP: Editora da Unicamp,2003. 419 - 471.

RUSCHMANN, Doris. Turismo e Planejamento Sustentável. 14. ed. Campinas, SP: Papirus, 2008: 83 - 92 / $100-102$ / $108-115$.

SIMÃO, Mํㅡㄹ Cristina Rocha. Preservação do patrimônio cultural em cidades. 1 ed. 1 reimp. - Belo Horizonte: Autentica, 2006. 23 - 37.

\section{Artigos retirados da internet:}

Caldas Novas: Brasil - O maior manancial hidrotermal do mundo. Disponível em: http://www.caldasnovas.com.br/história/index.html Acesso em: 07 jan.2009. 
CITY BRASIL - GOIÁS - CALDAS NOVAS. História da cidade.

Disponível em: http://www.citybrasil.com/br/go/caldasnovas/historia.php Acesso em 07 jan.2009.

CALDAS NOVAS - GOIÁS - BRASIL. Caldas Novas. Disponível em: http://www.imobiliariaemcaldasnovas.com.br/caldasnovas/caldasnovas index.htm Acesso em 07 jan.2009.

FÉRIAS. TUR.BR. Caldas Novas - Roteiros do Brasil - Região das Águas.

Disponível em: http://www.ferias.tur..br/informações/2107/caldas-novas-go.html. Acesso em 07 jan.2009.

IBGE - CIDADES @

Disponível em: http://www.ibge.gov.br/cidades/default2.php

Acesso 07 jan.2009.

CITY BRASIL - GOIÀS - RIO QUENTE - História da Cidade.

Disponível em: http://www.citybrasil.com.br/go/rioquente/historia.php Acesso em 19 fev.2009.

CALDAS NOVAS - Localização Geográfica.

Disponível em: http://www.geocities.com/thetropics/5342/localg.htm Acesso em 7 jan.2009.

PLANO DIRETOR DE CALDAS NOVAS - Lei № 1.118/03. Disponível em: http://www.caldasnovas.go.gov.br/planodiretor/lei da poilitica urbana.pdf. Acesso 16 fev.2009 
PLANO DIRETOR DE CALDAS NOVAS - Diretrizes Gerais - Proposta PDCN. http://www.caldasnovas.go.gov.br/planodiretor.

Acesso 16 fev.2009.

SILVA JUNIOR, Clovis C. da. Especulação Imobiliária e Loteamentos Irregulares: Um estudo de caso em Caldas Novas - GO.

Disponível em: http// www.revistamirante.net/4ed/5508.pdf Acesso em 08 de nov. 2008. 


\section{ANEXO A - MAPA DE ZONEAMENTO URBANO \\ DA CIDADE DE CALDAS NOVAS}

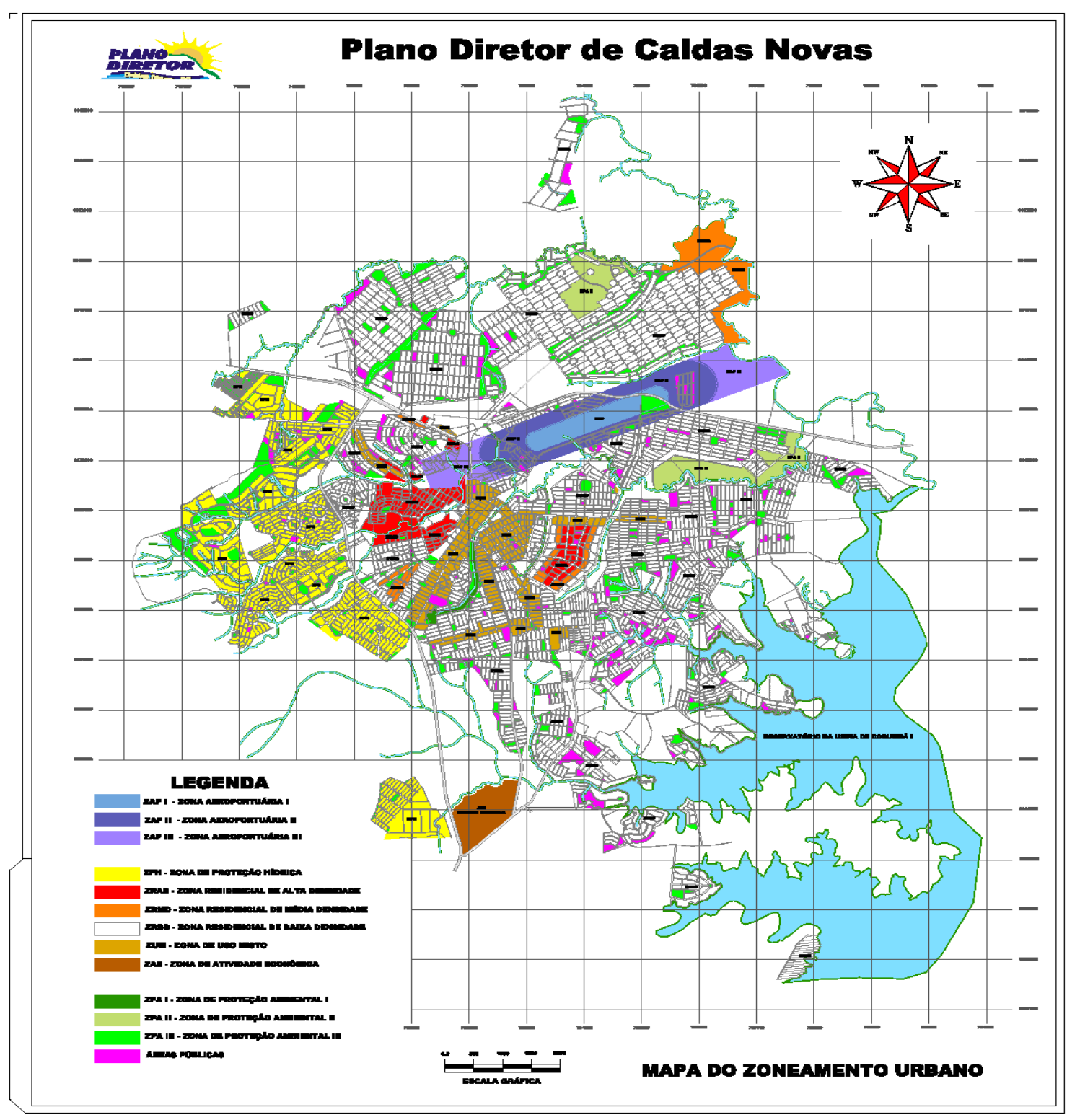




\section{ANEXO B - Encarte da Brasíliatur.}

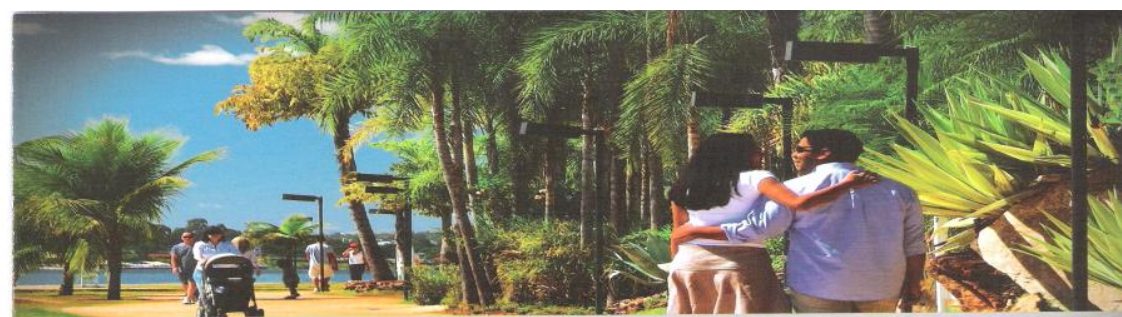

\section{BRASÍLIA CHAPADA DOS VEADEIROS}
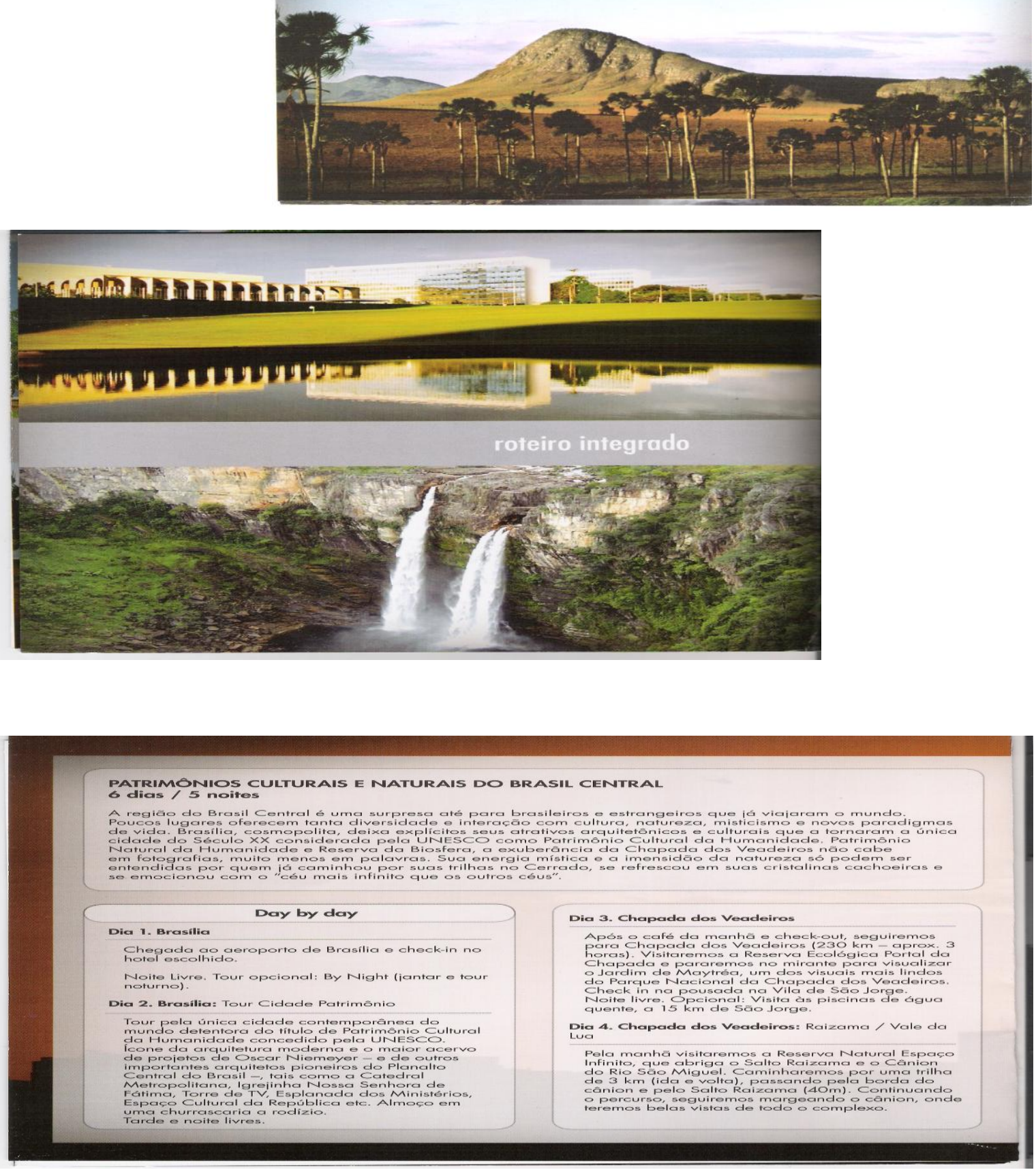


\section{ANEXO C - Encarte da Brasiliatur.}

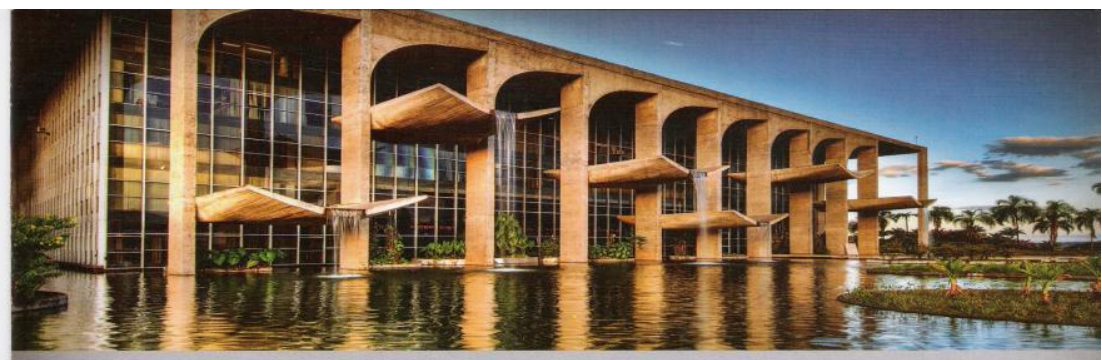

BRASÍLIA / PIRENÓPOLIS
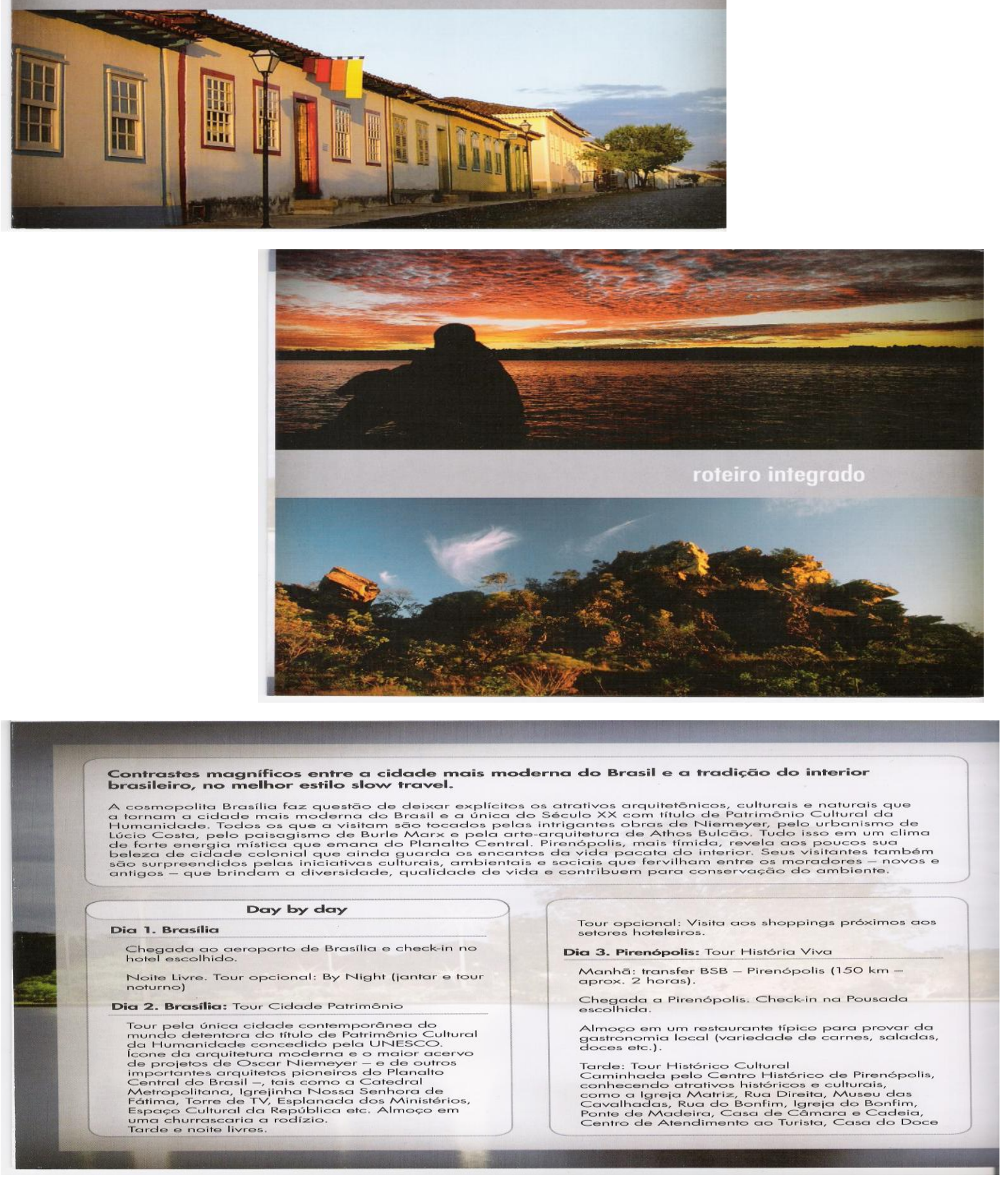